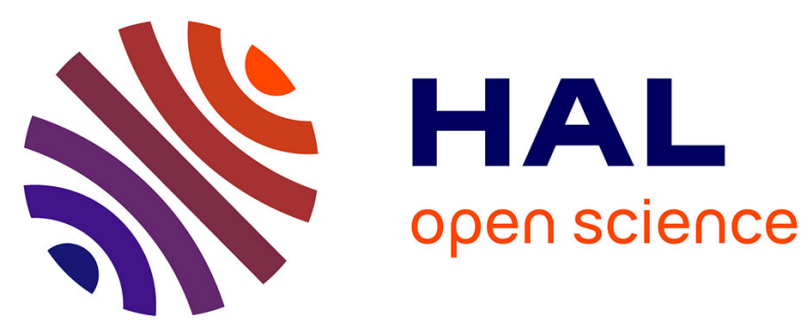

\title{
Ferrolysis induced soil transformation by natural drainage in Vertisols of sub-humid South India
}

Laurent Barbiero, M.S. Mohan Kumar, A. Violette, P. Oliva, J.J. Braun, C. Kumar, S. Furian, M. Babic, J. Riotte, V. Valles

\section{- To cite this version:}

Laurent Barbiero, M.S. Mohan Kumar, A. Violette, P. Oliva, J.J. Braun, et al.. Ferrolysis induced soil transformation by natural drainage in Vertisols of sub-humid South India. Geoderma, 2010, 156 (3-4), pp.173-188. 10.1016/j.geoderma.2010.02.014 . hal-02019926

\section{HAL Id: hal-02019926 https://hal.science/hal-02019926}

Submitted on 15 Feb 2019

HAL is a multi-disciplinary open access archive for the deposit and dissemination of scientific research documents, whether they are published or not. The documents may come from teaching and research institutions in France or abroad, or from public or private research centers.
L'archive ouverte pluridisciplinaire HAL, est destinée au dépôt et à la diffusion de documents scientifiques de niveau recherche, publiés ou non, émanant des établissements d'enseignement et de recherche français ou étrangers, des laboratoires publics ou privés. 


\title{
Ferrolysis induced soil transformation by natural drainage in Vertisols of sub-humid South
} India

L. Barbiero ${ }^{1,2,3^{*}}$, M.S. Mohan Kumar ${ }^{4}$, A. Violette ${ }^{1}$, P. Oliva ${ }^{1}$, J.J. Braun ${ }^{1,2,3}$, C. Kumar ${ }^{4}$, S. Furian ${ }^{5}$, M. Babic ${ }^{6}$, J. Riotte ${ }^{1,2,3}$, V. Valles ${ }^{6}$

${ }^{1}$ Université de Toulouse; UPS (SVT-OMP); LMTG; 14 Av, Edouard Belin, F-31062 Toulouse, France

${ }^{2}$ IRD; LMTG; F-31400 Toulouse, France

${ }^{3}$ CNRS; LMTG, UMR5563, F-31400 Toulouse, France

${ }^{4}$ Indo-French Cell for Water Sciences, Dept. of Civil Engineering, Indian Institute of Science, 560012, Bangalore.

${ }^{5}$ Laboratório de Pedologia, Departamento de Geografia, Universidade de São Paulo C.P. 8105, 05508-900, São Paulo, Brazil

${ }^{6}$ Laboratoire d'Hydrogéologie Appliqué, Université d'Avignon et des Pays du Vaucluse, 33, rue Pasteur, F-84000 Avignon, France.

*corresponding author: barbiero@lmtg.obs-mip.fr

\begin{abstract}
In sub-humid South India, recent studies have shown that black soil areas (Vertisols and Vertic Intergrades), located on flat valley bottoms, have been rejuvenated through the incision of streambeds, inducing changes in the pedoclimate and soil transformation. Joint pedological, geochemical and geophysical investigations were performed in order to better understand the ongoing processes and their contribution to the chemistry of local rivers. The seasonal rainfall causes cycles of oxidation and reduction in a perched watertable at the base of the black soil, while the reduced solutions are exported through a loamy sand network. This framework favours a ferrolysis process, which causes low base saturation and protonation of clay, leading to the weathering of 2:1 then 1:1 clay minerals. Maximum weathering conditions occur at the very end of the wet season, just before disappearance of the perched watertable. Therefore, the by-products of soil transformation are partially drained off and calcareous nodules, then further downslope, amorphous silica precipitate upon soil dehydration. The ferrolised area is fringing the drainage system indicating that its development has been induced by the streambed incision. The distribution
\end{abstract}


of ${ }^{14} \mathrm{C}$ ages of $\mathrm{CaCO}_{3}$ nodules suggests that the ferrolysis process started during the late Holocene, only about $2 \mathrm{kyr}$ B.P. at the studied site and about $5 \mathrm{kyr}$ B.P. at the watershed outlet. The results of this study are applied to an assessment of the physical erosion rate $\left(4.8 \times 10^{-3} \mathrm{~m} / \mathrm{kyr}\right)$ since the recent reactivation of the erosion process.

Key words: Vertisol, Ferrolysis, Duripan, Calcareous Nodules, Physical Erosion Rate, Late Holocene; South India

\section{Introduction}

Vertisols and "black soils" with vertic properties (vertic Intergrades) cover over 335 million hectares worldwide (IUSS-ISRIC-FAO, 2006). They are mainly found in lower landscapes such as dry lake bottoms, river basins, lower river terraces, and other lowlands that are periodically wet. Although Vertisols has been reported to form under humid conditions (Nordt et al., 2004, Driese et al., 2005), they occur mainly in tropical and subtropical climates, and in semi-arid to sub-humid climates with distinct wet and dry seasons (Wilding and Tessier, 1988; Balpande et al., 1996; Vaidya and Pal, 2002, Barbiero et al., 2005). Because of the large proportion of smectite-type minerals in the clay fraction, Vertisols and vertic Intergrades have a strong buffering capacity and are resilient to diverse chemical conditions. Smectite minerals also require a base-rich environment for their retention in soil and a high $\mathrm{pH}$ to prevent hydrolysis into kaolinite. As a consequence, smectite-rich Vertisols and vertic Intergrades generally persist in areas with high $\mathrm{pH}$ and poor drainage.

Ferrolysis is one of many different processes that occur to alter soil. Ferrolysis involves cyclic reduction and oxidation of iron in an open system, which leaches displaced base cations and accelerates mineral weathering (Brinkman, 1970). Introduced by Brinkman, the notion of ferrolysis has been described as a dominant process in many parts of the world to explain the strong textural contrast of soils (and Paleosols, Wright et al., 1991) where bleaching and mottling are predominant features. Although most studies were carried out over thirty years ago (Brinkman et al., 1973; 1977; Brinkman and Wieleman, 1977; Brammer and Brinkman, 1977; Brinkman, 1979), recently several authors have mentioned ferrolysis as a probable process to explain Fe-Mn-oxides segregations, gleying, chloritisation (Singh et al., 1998), textural variation and low pH in soils (Schaefer et al., 2002, O'Geen et al., 2008). Since the eighties, several studies have questioned the incidence of ferrolysis in a number of previously reported sites (Eaqub and Blume, 1982; Boivin et al., 2004). Van Ranst \& De Coninck (2002) recently examined soils from Belgium and France that were considered to have formed mainly by ferrolysis. Assessment by chemical, mineralogical 
morphological, and micromorphological techniques showed that contrasting textures typically attributed to ferrolysis were more likely to have formed by clay translocation (Montagne et al., 2008). Similar findings by Favre et al. (2002) demonstrated that the reduction of structural iron in (2:1) clay during flooding in Vertisols from the Senegal valley resulted in a significant increase in the CEC value. As a result the ferrous iron produced was not sufficient to saturate the new sites on the complex, thus requiring external iron reduction for the displacement of exchangeable base cations (Boivin et al., 2004). Therefore, recent studies strongly indicate that the role of ferrolysis in soil formation has been overestimated. As such, the boundary conditions necessary for ferrolysis are largely unknown.

Our research team has been conducting parallel pedological, hydrological, geochemical and geophysical investigations on a small experimental watershed $\left(4.1 \mathrm{~km}^{2}\right)$ in sub-humid South India, in order to establish hydro-bio-geochemical balances (Braun et al., 2005). The study involved the assessment of chemical weathering and regolith thickness (Braun et al, 2009), determination of surface and groundwater balance, recharge and modelling, (Legchenko et al., 2006; Descloitres et al., 2008, Maréchal et al., 2009; Ruiz et al., 2010; Parate et al., submitted), physical erosion calculations (Barbiero et al., 2007) and, the appraisal of soil cover dynamics. At the watershed scale, estimates of element exportation are only rarely consistent with long term weathering rate assessments. There exists a need to perform local- scale studies of present-day, rapid soil forming processes to fill this knowledge gap. The cover consists mainly of red soil (Chromic Luvisols and small spots of Ferralsols) and black soil (Vertisols and vertic Intergrades). Black soils located in lowlands frequently contain contrasted loamy sand bleached volumes suggestive of soil transformation that is suspected to influence the water chemistry at the outlet of the watershed. In addition, silica cemented horizons have been observed at several points along the streambed and are likely to be integral components of the soil system. Understanding the processes responsible for these pedological features is key to linking chemical weathering rates with present-day chemical exportation at the watershed scale. The objective of this study is twofold: first, it aims to understand the currently ongoing soil transformation processes and the parameters controlling their development; and second, it intends to assess the consequences of these processes on the chemistry of water flowing out of these black soil areas.

\section{Materials and methods}

The Western Ghats, parallel to the western coast of the Peninsula in Southern India, form an orographic barrier inducing a climatic gradient. The annual rainfall decreases progressively from roughly $5000 \mathrm{~mm}$ in the west, to less than $750 \mathrm{~mm}$ at $80 \mathrm{~km}$ to the east (Pascal, 1982; Sehgal and Mandal, 1995). The landscape geomorphology changes from convex hills alternating with flat 
floors to long concave glacis (Gunnell and Bourgeon, 1997; Gunnell, 2000). In connection with the geomorphological changes, we find thin red soils (Chromic Luvisol; IUSS-ISRIC-FAO, 2006) associated with Ferralsols and black soils (Vertisol, vertic Intergrades) in the climatic semi-humid transition area, and further east calcic Luvisol and calcic Vertisol in the semi-arid area (Murthy et al., 1982; Pal and Deshpande, 1987; Bourgeon, 1991; Radhakrishna and Vaidyanadhan, 1994; Jacks and Sharma, 1995; Shiva Prasad et al., 1998; Gunnell, 2000). Along this climatic sequence, the passage in the clay mineralogy from the kaolinite-dominated humid area to the smectite-dominated semi-arid area is achieved progressively via an intermediate area with 2:1 K-clay such as illite and sericite (Bourgeon and Pedro, 1992).

The study was carried out on a $4.1 \mathrm{~km}^{2}$ watershed (Fig. 1) located in the conserved Bandipur National Park close to the Mule Hole check post at $11^{\circ} 44^{\prime} \mathrm{N}$ and $76^{\circ} 27^{\prime} \mathrm{E}$ (Karnataka state, Chamrajnagar district). The watershed is located in the sub-humid climatic transition zone, with a mean annual rainfall spread over 20 years of about $1120 \mathrm{~mm}$ and annual average temperature of $23^{\circ} \mathrm{C}$. The climate is characterized by recurrent but non-periodic droughts, depending on monsoon flows. The studied area is primarily undulating with gentle slopes, with elevations varying from 800 to $910 \mathrm{~m}$ above mean sea level, and incised by a stream network. Streams are temporary flowing for a few hours to a few days after stormy events during the rainy season (June to October). The streambeds are steep-sided up to 4 meters down compared to the valley floor. The vegetation consists of a dry deciduous forest (Agarwala, 1985). The area is developed on crystalline rocks of the Precambrian Dharwar supergroup (Moyen et al., 2001) consisting of peninsular gneiss intermingled with mafic and ultramafic rocks of the volcano-sedimentary Sargur serie (Shadakshara Swami et al., 1995). The peninsular gneiss represents about $83 \%$ of the watershed area (Barbiero et al., 2007). Previous observations suggest that both topography and lithology have influenced the formation and distribution of soils in the landscape. Black soils mainly occur in the valley bottom and to a lesser extend are also found at certain zones along the slope and at the crest line (Lacarce, 2005). On the other hand, black soils may be related to the presence of amphibolites, but are not exclusively on amphibolites since they are also frequently observed on gneiss saprolite (Barbiero et al., 2007). The relatively high proportion of smectite clay minerals in black soils causes considerable shrink-swell conditions, which induce crack formation and distinctive structural elements such as wedge-shaped aggregates with smooth- or slikensided surfaces. A previous study showed the relative chronology in the development of the downslope soil cover (Barbiero et al., 2007). This work highlighted that the geomorphology of valley bottoms have been recently reactivated with the development of streambeds. Study on the soil layout at different scales also revealed that thin black soils, unlike thick black soils, have guided the development of the drainage network. Such landscape development was favoured by the presence of saprolite, at less than $2 \mathrm{~m}$ 
deep, and reached by the cracks during the dry season. As a consequence, streambeds meander within the thin black soil, skirting around the thick black soil areas. Recent incisions created by the streambeds are thought to have contributed to changes in the pedoclimate into the black soils, and consequently could have reactivated some soil forming processes. These processes may contribute to the chemistry of the local rivers.

A $5000 \mathrm{~m}^{2}$-black soil area located at the bottom part of the watershed was targeted for the study (Fig. 1). This area was defined using electromagnetic induction, vegetation survey and direct soil observations. It is surrounded and incised by two temporary streams (Fig. 2), the main stream of the watershed and a short tributary, which is less incised, but whose depression consists of successive triangular ponds (Fig 3a). The black soil area appears as a plateau that is elevated at 2 to $4 \mathrm{~m}$ from the bottom of the streambed (Fig. 2).

Prospecting fieldwork: The prospecting fieldwork was carried out in 3 steps. First, soil transects were studied along the slope from the black soil area to the streambed (transects T, U and V on Fig. 2). Since we observed similar soil organisations, only transect $\mathrm{T}(30 \mathrm{~m})$ will be presented here. Another $60 \mathrm{~m}$-soil transect was studied along the depression of the streambed (transect S on Fig. 2). The soil pattern was studied in detail along 21 auger holes and 3 excavated pits, which revealed the geometrical relationships between the different horizons (Boulet et al., 1982; Fritsch et al., 1992) identified from basic field observations (Munsell chart colour, texture, structure, macrovoids, presence of coarse elements, intensity of biological activity, etc). Second, dense electromagnetic measurements were carried out along the transect $\mathrm{T}$ in an attempt to establish a relationship between the soil layout and the electromagnetic response. Electromagnetic induction using portable instruments is becoming rapid widespread technique for soil survey in general. This method presents several advantages: 1. measurement is nearly immediate and can be taken by walking across the surface; 2 . the large volume of measured-soil reduces the variability and therefore helps in the interpolation of the conductivity trends; 3 . the contact between the soil and the sensor is not necessary, hence it is valid even in cases of dry topsoil (Hendrickx et al., 1992). The instrument (EM38 device, Geonics Ltd, Ontario, Canada) measures apparent soil electrical conductivity (ECm) in milliSiemens per metre $(\mathrm{mS} / \mathrm{m})$. It has a transmitter and repeater coil separated $1 \mathrm{~m}$ apart. When used in the vertical mode $\left(\mathrm{ECm}_{\mathrm{v}}\right)$, almost $75 \%$ of the signal is estimated to come from the top $1.8 \mathrm{~m}$ of the soil, whereas in the horizontal mode $\left(\mathrm{ECm}_{\mathrm{h}}\right)$ about $75 \%$ of the signal is estimated to come from the top $1 \mathrm{~m}$ of soil (McNeill, 1980). The measurements were made in both vertical and horizontal modes at every metre along transect $\mathrm{T}$. 
Third, the entire black soil area was surveyed using EM38 in a vertical mode and coupled with GPS in order to draw the lateral changes in the soil cover. The distance between two successive $\mathrm{ECm}_{\mathrm{v}^{-}}$ measurement points was approximately 5 to $10 \mathrm{~m}$. The topography was surveyed using a teodolite.

Zero-tension lysimeters: Watertable samplers were installed during the dry season along the selected transect $\mathrm{T}$ (upslope and downslope) and along the drainage area (transect $\mathrm{S}$ ) to the confluence with the main stream of the watershed (Fig. 2). In order to monitor the water chemistry at fixed points the samplers were placed along the slope, streambed and drainage areas at different depths (see Figure 4) in a network of loamy sand volumes where a temporary saturation by a perched watertable was expected. Because of the presence of wild elephants in the region, it was not possible to set up in situ electrode ( $\mathrm{pH}, \mathrm{EC}$ and redox) monitoring and sampling of the groundwater. The watertable samplers consist of a simplified model of zero-tension lysimeter presented by Maitre (1991). The lysimeter is a $100 \mathrm{ml}$ closed polypropylene container, with holes measuring $2 \mathrm{~mm}$ in diameter and wrapped with a synthetic fabric to prevent clogging by soil particles. A polypropylene capillary tube (1mm inner diameter) was inserted in the cap of the container, and reaches the soil surface allowing water samples to be collected. Auger holes $(7 \mathrm{~cm}$ in diameter) were made down to the selected horizon where the sampler was placed, and the hole was filled and compacted again in the same order of the excavated horizons. This type of sampler limits the contact between the soil solution and the outer atmosphere, and therefore allows retention of the in situ redox conditions of the solution until the sampling.

Sampling: Water samples were irregularly taken according to the rainfall events during the wet season (2005, 2006 and 2007). They were collected from the lysimeters by gentle pumping with a hand-held vacuum pump in order to prevent drastic changes in the redox conditions. The sampling system is designed so that the solution is driven by the capillar to the sensitive part of the platinum probe without previous contact with the outer atmosphere. Redox potential (Eh) was immediately measured in the sampled solution ( 2 seconds) and the first value (the lowest one) was considered to be close to the redox potential existing in the perched watertable. Temperature (T), conductivity (EC) and $\mathrm{pH}$ were determined in the field before samples were filtered $(0.2 \mu \mathrm{m}$ cellulose-acetate filter) and collected in acid washed polyethylene containers.

A total number of 104 soil samples were collected at every $20 \mathrm{~cm}$ during auger hole drilling. Additional samples were taken for SEM observation of cemented soil horizons and mineralogical analysis to characterize the clay fraction distribution. $\mathrm{CaCO}_{3}$ nodules were collected for chemical analysis and radiocarbon dating in order to determine origin and relative development along the studied soil sequence $\mathrm{T}$. 
Laboratory work: In order to appreciate the geochemical profile of the soil solution and its variations along the selected sequence, and owning to the difficulty to collect directly free solutions in the vadose zone, saturated extracts were obtained from the soil samples. Electrical conductivity was measured in the saturated pastes after a 4-hour equilibration whereas soil $\mathrm{pH}$ was analysed in 1:1 soil:water ratio suspensions following 30-min equilibration. The solutions from both extracts and lysimeters were analysed in the same conditions.

Major elements in water were analysed using ion chromatography and atomic absorption spectrometry. Alkalinity was measured by acid titration and silica was measured by colorimetric ammonium-molybdate method. Minor and trace elements were determined by ICP-MS, and analysis were interspersed and checked with standard reference material (SLRS4). Detection limits are about $10 \mathrm{ppt}$ for trace elements.

Because the carbonate nodules found in the studied area were very weak, it was not possible to select the micritic phase at the central part. Therefore, analyses were performed on whole crushed nodules. Nodules were ground in agate mortar, and then aliquots of $150 \mathrm{mg}$ of calcitic powder were leached with $50 \mathrm{ml}$ of $0.25 \mathrm{~N}$-Suprapur $\mathrm{HCl}$. The tube was sonicated for $15 \mathrm{~min}$ and centrifugated at $3000 \mathrm{rpm}$ for $4 \mathrm{~min}$. The soluble phase was separated, dried and dissolved again in $\mathrm{HNO}_{3}$. The organic matter was removed by adding $1 \mathrm{ml}$ of hot Suprapur $\mathrm{H}_{2} \mathrm{O}_{2}$.

Other rock and fine ground $(<2 \mathrm{~mm})$ soil fractions were analyzed by ICP-MS after $\mathrm{LiBO}_{2}$ fusion at the SARM-CRPG of the CNRS (Vandoeuvre-lès-Nancy, France). In order to eliminate the effect related to nuclear stability and nucleosynthesis, rare earth (REE) abundances were normalized to an average abundance in the local peninsular gneiss (Braun, personal communication). The presence of isolated volumes of the saprolite still preserving the orientation of the original material in the lower part of the vertisol profile together with the absence of morphological discontinuity or evidence of alluvial/colluvial deposits, suggests for vertisol development on autochthonous material derived from the peninsular gneiss (Barbiero et al., 2007). Cerium anomalies were calculated in order to link the soil parent material, the soil solution and different solid phases along the sequence $\mathrm{T}$, through redox sensitive processes. The calculation was made according to $\mathrm{Ce} / \mathrm{Ce}^{*}=\mathrm{Ce}_{\mathrm{N}} /\left(\mathrm{La}_{\mathrm{N}}\right.$. $\left.\operatorname{Pr}_{N}\right)^{1 / 2}$. $\mathrm{Ce} / \mathrm{Ce}^{*}$ denotes the $\mathrm{Ce}$ anomaly and the subscript $\mathrm{N}$ in the equation represents the abundance of the element normalized to the peninsular gneiss.

The soil samples were air-dried, gently ground, and sieved to separate the $<2 \mathrm{~mm}$ fraction. Particle size distribution was determined by the pipette method, after organic matter removal with $\mathrm{H}_{2} \mathrm{O}_{2}$ and dispersion with Na-hexametaphosphate. Cation exchange capacity was determined by ion displacement with $1 \mathrm{M} \mathrm{NH4OAc}(\mathrm{pH} 7)$, and the exchangeable cations were measured by atomic 
absorption. Total carbon content in the samples was determined by dry combustion in an elemental analyser (Thermoquest CN 2100). Organic matter was estimated at 1.724 total carbon (\%).

The clay fraction $(<2 \mu \mathrm{m})$ was analysed for mineralogy by X-ray diffraction (XRD) of glassoriented specimens saturated with $\mathrm{Mg}, \mathrm{Mg}+$ glycerol, $\mathrm{K}$ and $\mathrm{K}+$ glycerol. The relative abundance of clay mineral groups was determined semi-quantitatively from the area under selected XRD peaks, following standard procedures of Biscaye (1965). Since XRD is semi-quantitative with an accuracy of about $10 \%$ of the relative clay mineral abundance, our data values are presented to the nearest $1 \%$ (Kahle et al., 2002).

Radiocarbon dating: ${ }^{14} \mathrm{C}$ ages were measured at the LHA (Avignon, France) in order to investigate the chronological frame in the soil transformation. Pulverized carbonate sample were acidified with orthophosphoric acid for $\mathrm{CO}_{2}$ extraction. The lithium carbide obtained from the extracted $\mathrm{CO}_{2}$ was hydrolized into acetylene. Counts were then performed by liquid scintillation (low level Tricarb 1550) on synthesized benzene from the trimerization of acetylene. Benzene, with an activity of $38.3 \mathrm{~Bq} / \mathrm{g}$, was used as standard. Radiocarbon ages were calculated using the half lifetime of 5730 years and expressed as years before present (BP).

Data treatments: A geostatistical treatment was carried out on $\mathrm{ECm}_{\mathrm{v}}$ data before kriging. The krigged map was built from a model fitted on the sample variogram using the least squares method. A principal component analysis based on the correlation matrix was performed on normalized centred variable $\mathrm{pH}, \mathrm{EC}$, major elements, and silica. The principal component analysis was used in order to quantify and sort the data, and the chemical parameters according to the factors that might explain the variability in the chemistry of the samples set. The factorial axes identified with this method are orthogonal and are the result of processes that are independent between each other. The PCA was first applied to the full data set, while in a second step the same treatment was applied to both saturated extracts and samples from lysimeters separately. The saturation, with respect to calcite, was calculated using PHREEQC database (Parkhurst, 1995).

\section{Results}

ECm Survey: The electromagnetic conductivity of the acquired data ranged from 11 to $96 \mathrm{mS} / \mathrm{m}$ with a mean of about $50 \mathrm{mS} / \mathrm{m}$, and a standard deviation of $21 \mathrm{mS} / \mathrm{m}$. There was no significant anisotropy detected when comparing the raw and directional variogram. The absence of nugget and the range value $(25 \mathrm{~m})$, which is higher than the distance between the ECm measurements points $(<10 \mathrm{~m})$, indicate that the density of prospecting points is sufficient for a good assessment of $\mathrm{ECm}_{\mathrm{V}}$ distribution. The electromagnetic conductivity was not distributed regularly on the study area. Higher conductivity values $(>80 \mathrm{mS} / \mathrm{m})$ were observed along the slopes, i.e. at the edge of the black 
soil area, whereas lower values occurred in the depression of the talweg $(<50 \mathrm{mS} / \mathrm{m})$ and at the central part of the black soil area $(<70 \mathrm{mS} / \mathrm{m})$.

2D soil morphology: Fig. 4 shows the soil distribution pattern along the cross section T, which started from the central part of the black soil area, intersected an area with higher $\mathrm{ECm}_{\mathrm{v}}$ values, and ended at the streambed. Upslope, the soil was roughly 2.6 meter thick with a light grey (7.5YR5.5/2) sandy loam to sandy-clay-loam topsoil horizon (horizon 1), overlaying a dark brown (5 to $7.5 \mathrm{YR} 3 / 2$ to $2 / 2$ ) thick heavy clay horizon with vertic properties (horizon 2). When dry, the cracks reached about $1.5 \mathrm{~m}$ deep and wedge-shaped aggregates occurred down to about $1.2 \mathrm{~m}$ deep. Further deep, there was a progressive transition towards the saprolite of the gneiss. Towards downslope the black soil preserved roughly the same morphology although the thickness decreased progressively to reach only $1 \mathrm{~m}$ close to the talweg. Three different changes in the clay material were observed, which distinguished three domains laterally along $\mathrm{T}$. They are:

1. The occurrence of highly contrasted light brown (7.5YR4.5/3) elongated loamy sand volumes (15 to $50 \mathrm{~cm}$ long and 2 to $10 \mathrm{~cm}$ wide; Fig. $3 \mathrm{~b}$ and $3 \mathrm{c}$ ). The abrupt contrast between these volumes and the dark clay matrix ( 5 to $7.5 \mathrm{YR} 3 / 2$ to $2 / 2$ ) was frequently emphasized by a rust coloured edging of iron oxide having an abrupt boundary against loamy sand volumes and a diffuse boundary against the clay matrix. We observed no clay coatings at contacts between the loamy sand volumes and clay matrices. Two horizons were distinguished: in horizon 3, loamy sand volumes occurred but the clay matrix remained dominant, whereas in horizon 4 , the loamy sand material prevailed. In both horizons 3 and 4, the loamy sand volumes were connected and formed a network where a watertable flowed during the rainy season. The lysimeters along the slope were installed in horizon 4.

2. The occurrence of calcareous nodules $(1 \mathrm{~cm}$ in diameter) into the clay matrix. These nodules were distributed into a tongue-shaped volume, which was about $1 \mathrm{~m}$ thick in its lower part and about 0.3 $\mathrm{m}$ in its upper one. The presence of carbonates extended towards downslope the domain with loamy sand volumes. The ${ }^{14} \mathrm{C}$-dating ages of the nodules ranged from $1.63 \pm 0.07$ to $1.11 \pm 0.07 \mathrm{kyr} \mathrm{BP}$. Dating ages gave younger results from the bottom to the top of the horizon, and from downslope to upslope along the sequence. Therefore, this data permits the proposition of a growth model for the tongue-shaped volume with carbonates, as presented in Fig. 4.

3. A bleaching of the clay matrix, which progressively turned sandy-clay then sandy loam at the bottom part of the sequence, allowed for 3-additional horizons to be distinguished. The topsoil consisted of a $0.2 \mathrm{~m}$-thick sandy loam horizon (10 YR 4/2 to 5/3) that was hard with a massive structure and was cemented (horizon 5). Below, we found a 0.3 to $0.4 \mathrm{~m}$-thick sandy loam bleached (10 YR 6/3) horizon (6). At the upper part of this horizon, although the texture was sandy loam, the 
material was hard and a coarse structure with vertical and sub-horizontal cracks was observed. The wedge shape and the size of the blocks were similar to those described in the swelling clay horizon 2 with vertic properties. The lower part of horizon 6 is much softer and less cemented. Further deep, we observed a sandy loam 0.5m-thick and hard horizon 7 (10 YR 4/3 to 5/3). SEM observations showed typical silica coating and confirmed that the cementation was due to amorphous silica (Fig. $3 d)$.

Horizon distributions along studied areas: The EM38 ECm values along T are plotted in Fig. 4, and allowed us to establish some concordances with the soil morphology. $1-\mathrm{ECm}_{\mathrm{v}}$ is always higher than $\mathrm{ECm}_{\mathrm{h}}$ in agreement with the presence of conductive clay horizon at depth, and less conductive topsoil horizons. At $12 \mathrm{~m}, \mathrm{ECm}_{\mathrm{v}}$ and $\mathrm{ECm}_{\mathrm{h}}$ showed the same value in agreement with the disappearance of the loamy sand topsoil horizon, as expected from the EM38 response curves (McNeill, 1980). 2 - Upslope, $\mathrm{ECm}_{\mathrm{v}}$ values were about 60 to $70 \mathrm{mS} / \mathrm{m}$. Then the values increased over $80 \mathrm{mS} / \mathrm{m}$ along the slope, in concordance with the occurrence of calcareous nodules. 3 Downslope, $\mathrm{ECm}_{\mathrm{v}}$ values decreased in agreement with the sandy loam texture of the soil in the depression.

The concordance between high $\mathrm{ECm}_{\mathrm{v}}$ values and the presence of calcareous nodules was applied to the survey of nodule occurrence on the studied area and was verified by hand auger observations. The distribution presented in Fig. 2 showed that the nodules occurred along the slope towards the stream, but not in the centre of the black soil area.

Calcareous nodules collected at the lower part of transects U and V (Fig. 2) gave dating ages of $1.70 \pm 0.06 \mathrm{kyr}$ and $2.31 \pm 0.05 \mathrm{kyr}$, respectively.

Soil layout along the depression: Fig. 5 shows the distribution of the cemented horizons along the depression. Two cemented horizons were distinguished: a deep one (horizon 7 on Fig. 4), which was continuous and constituted the bottom of the ponds, and a shallow one at topsoil (horizon 5 on Fig. 4), which was discontinuous.

Clay mineralogy: The mineralogy of the $<2 \mu \mathrm{m}$ fraction consisted mainly of kaolinite, smectite and illite. The relative abundance of the clay mineral group, organic matter and the complex base saturations are presented in Table 1. Kaolinite was dominant in the clay fraction of all samples. Smectite formed about $40 \%$ of the $<2 \mu \mathrm{m}$ fraction in horizon 2 with vertic properties, $35 \%$ in horizon 3 , and only to $15-20 \%$ in horizons 4 and 1 . A peak at $0.15 \mathrm{~nm}$ for the 060 reflection indicated that smectite is dioctahedral and its expansion beyond $1.4 \mathrm{~nm}$ of K-saturated, glycerolsolvated, oriented samples suggested a small layer charge (Christidis and Eberl, 2003). The 
exchange complex was nearly saturated in horizon 2 and 3, but the base saturation decreased to about $90 \%$ in the topsoil horizon 1 and to $65 \%$ in horizon 4 .

Few changes occurred at the local scale in the kaolinite, which were observed in horizon 3 . In the clay matrix the peak of kaolinite is centred at $7.14 \AA$ and nearly symmetrical. At the contact with the sandy network, (for example, at only $5 \mathrm{~cm}$ apart from the previous sample) the crystallinity, that was estimated from the width at half maximum of the 001 line, decreased, and the peak became asymmetrical towards smaller $2 \theta$ values (increasing interlayer distance).

\section{Chemistry from saturated extracts and lysimeters:}

A summary for $\mathrm{pH}$, major elements and silica statistics in saturated extracts and lysimeters samples are presented in Table 2 and 3. Large ranges are observed in the $\mathrm{pH}$ values in saturated extracts (2.06) and in the lysimeters (2.89) indicating a contrasted environment in time and space. The examination of the singular values revealed that the two axes of the first factorial plan of the PCA accounted for $41.6 \%$ and $26.7 \%$ in the variance of the data set. The first factorial plan clearly discriminates two groups of samples. One set of samples was from saturated extracts with a $\mathrm{Na}-\mathrm{Cl}$ neutral chemical profile, and the other set was from the lysimeters, with a $\mathrm{Na}-\mathrm{HCO}_{3}$ chemical profile (Fig. 6), more alkaline and with significantly higher $\mathrm{Ca}^{2+}$ and $\mathrm{Mg}^{2+}$ content (Table 2 and 3). This bias along the first factorial plan justified the study of the chemical variability within each group.

Among the saturated extracts, the 3 main factorial axes of the PCA explained $60.9 \%$, $13.5 \%$ and $10.4 \%$ of the variance (Table 4). The first axis permitted the categorical discrimination of the samples according to their total concentration (Fig. 7). Fig. 8 indicated that the first factor of variability was mainly distributed at the midslope (from profile $\mathrm{H} 2$ to $\mathrm{H} 8$ ) and was roughly in agreement with the presence of calcareous nodules and high ECm values (Fig. 4). The second axis discriminated samples with relatively high $\mathrm{SO}_{4}{ }^{2-}$ content (Fig. 7), mainly located at the base of the profiles $\mathrm{H} 9$ and $\mathrm{H} 2$, to the rest of the sampling. It also accounted for the topsoil horizon, which presented higher $\mathrm{SO}_{4}{ }^{2-}$ and $\mathrm{K}^{+}$values (Fig. 8). The second axis most likely denoted both a variability induced by the lithology, and a secondary process induced by throughfall and organic matter decomposition, influencing the solution at the topsoil. The third factorial axis discriminated the most alkaline extracts with relatively low silica. These extracts arise from the upper part of the tongue-shaped volume of carbonates occurrence.

The perched watertable was established only a few days after the first rainy events in the depression (lysimeters $\mathrm{C}_{\mathrm{e}}, \mathrm{C}_{\mathrm{f}}$ and $\mathrm{C}_{\mathrm{g}}$ ) and along the sequence (lysimeters $\mathrm{C}_{\mathrm{h}}, \mathrm{C}_{\mathrm{i}}$ and $\mathrm{C}_{\mathrm{j}}$ ). Among the samples from the lysimeters, the PCA showed mainly 3 axes responsible for the variance $(43.9 \%, 21 \%$ and $10.8 \%$, respectively; see Table 5). The first factorial axis opposed samples with high concentration, 
collected from $C_{h}$ in the period September-October 2006, to diluted samples collected in the depression from $C_{g}, C_{f}$ and $C_{e}$ on August $23^{\text {rd }}$, 2007. It appeared that this first axis differentiate samples according to their total concentration (Fig. 9). The second axis compared samples first with high silica and fluoride concentrations to samples with relative high potassium content. In particular, it differentiated all samples from $C_{i}$ and samples from $C_{j}$ and $C_{h}$ collected at the very end of the rainy season 2006 (November $10^{\text {th }}$ ) due to their high silica contents. Therefore, this second factorial axis denoted a process supplying silica in the soil solution along the slope, which was stronger at $\mathrm{C}_{\mathrm{i}}$, and seemed to be particularly active at the end of the wet season. Fig. 10 shows the monitoring of the chemistry of $C_{i}$ and $C_{h}$ along the year 2006. The same trends are observed for silica contents along the wet season, with relatively high values, but increasing significantly within only two days, from November $8^{\text {th }}$ to $10^{\text {th }}$. Base cations $\left(\mathrm{Na}^{+}, \mathrm{Ca}^{2+}, \mathrm{Mg}^{2+}\right)$ and alkalinity increased slightly in $C_{i}$ and $C_{j}$ (data not shown), yet these increased significantly in $C_{h}$ during the second half of the wet season. The saturation with respect to calcite is reached in $C_{h}$, whereas the solution collected from $\mathrm{C}_{\mathrm{i}}$ or $\mathrm{C}_{\mathrm{j}}$ needs to concentrate 3 to 5 times to saturate. A tremendous drop in alkalinity and base cations is noted from the last samples collected at the end of the season.

The third axis discriminated the samples according to their $\mathrm{SO}_{4}{ }^{2-}$ amounts. Because $\mathrm{SO}_{4}{ }^{2-}$ is present at low concentrations (Table 3), this third axis was considered as background noise in the samples.

\section{Eh-pH monitoring in lysimeters:}

The Eh-pH monitoring is presented in Fig. 11 and 12. Similar trends are observed annually. The redox potential is high when the rainy season begins, with values around $+500 \mathrm{mV}$ and $\mathrm{pH}$ close to 7.2 in the depression, 7.4 in $C_{h}$ and $C_{i}$, and 7.7 in $C_{j}$. During the rainy season, Eh values decreased and $\mathrm{pH}$ increase. At the end of the rainy season the Eh increased and the $\mathrm{pH}$ decreased. However, clear differences are observed between lysimeters from the slope and from the depression. Along the slope, Eh potential values dropped sufficiently low to reduce and mobilize $\mathrm{Fe}$, and was maintained below this threshold for a period of one month (Fig. 12). In the depression, values hardly reached $+120 \mathrm{mV}$ and only for very short periods (Fig. 11). A difference was also observed in the $\mathrm{pH}$, which drastically dropped at the very end of the rainy season ( 1 to $1.5 \mathrm{pH}$ units in a few days) in the lysimeters along the slope, just before the disappearance of the watertable whereas the redox potential started increasing. As a consequence, the $\mathrm{pH}$ returned to the same value as that observed at the beginning of the rainy season in the lysimeters of the depression, whereas it was much lower in the lysimeters from the slope. This trend was clearly detected in 2005 and 2006. It was less evident in lysimeter $C_{i}$ in 2007 , whereas the monitoring was unfortunately interrupted in lysimeters $C_{j}$ and $C_{h}$, that were destroyed by wild elephants. 
Cerium anomalies in the black soil groundmass, lysimeters and calcareous nodules are presented in Table 6. In black soil, a slight negative anomaly is detected, which increases in the solutions from the lysimeters and in the carbonate phase of the calcareous nodules. Among the lysimeters, the negative anomaly is detected less at $\mathrm{C}_{\mathrm{g}}$, located upstream in the depression (sequence $\mathrm{S}$ ), we then observe higher levels at lysimeter $\mathrm{C}_{\mathrm{e}}$, at the confluence of the two streams, and is at maximum levels at $\mathrm{C}_{\mathrm{i}}$ located along the slope in the sandy network.

\section{Discussion:}

Both lysimeters and pastes samples have very contrasted chemical compositions and cannot develope from each other by a simple process of concentration-dilution. Saturated extracts represent the quality of the soil solution and its variability along the sequence, whereas the free water in sandy networks reflect the dynamics of the seasonal perched watertable and the weathering conditions that prevail at a very local scale at the merging of the black soil area. Our first focus was based on the chemistry in lysimeters.

The seasonal nature of rainfall creates repetitive cycles of oxidized and reduced conditions. At the beginning of the rainy season, the presence of open cracks favours the quick occurrence of a perched watertable at the base of the black soil, just above the transition with the saprolite of the gneiss (Barbiero et al., 2007). The solution in the watertable is well aerated, where dissolved $\mathrm{O}_{2}$ is the main oxidant and the microbial respiration consumes available oxygen. Then swelling and sealing of cracks prevent continuous $\mathrm{O}_{2}$ flux towards the watertable. The consumption rate of respiration exceeds the $\mathrm{O}_{2}$ supply, and once oxygen is consumed, specialized bacteria colonies continue to consume organic matter and respire thereby utilizing oxidants other than oxygen. The redox potential continues to decrease. $\mathrm{NO}_{3}{ }^{-}$is usually the second oxidant used and it disappears at about $+250 \mathrm{mV}$, then $\mathrm{Mn}^{2+}$ appears at about $+225 \mathrm{mV}$ and $\mathrm{Fe}^{2+}$ at about $+120 \mathrm{mV}$ for a $\mathrm{pH}$ value at roughly 7. These redox potential limits are not fixed values. They are subject to the effects of temperature, $\mathrm{pH}$, availability and type of organic matter substrates (Hobson and Dahlgren, 1998).

Eh potential values decrease sufficiently to reduce nitrate, manganese, and iron in the watertable along the slope, whereas the reduction of iron is not likely in the depression where Eh potential remains relatively high. In this framework, and together with the considerations detailed below, it appears that there is a transformation through a ferrolysis process occurring only along the slope in the detected sandy network of horizons 3 and 4 .

Local scale observations in the sandy network: Reduction reactions consume protons $\left(\mathrm{H}^{+}\right)$ resulting in an increase in soil $\mathrm{pH}$ during the period of reduction. This process is reflected as the inverse relationship between $\mathrm{pH}$ and $\mathrm{Eh}$ values (Eh decreases and $\mathrm{pH}$ increases) in all the lysimeters 
(Fig. 11 and 12). The alkalinity produced through reduction reactions appears as carbonate alkalinity in the soil solution, due to the high dissolved $\mathrm{CO}_{2}$ resulting from biotic respiration (Fig. 10). At the same time, the soil solution becomes enriched in base cations (calcium, magnesium and sodium), which are probably displaced by reduced iron from the exchange capacity. The abovementioned changes in the chemistry are detected in $\mathrm{C}_{\mathrm{j}}$ (not shown) and $\mathrm{C}_{\mathrm{i}}$, but are much stronger in lysimeter $\mathrm{C}_{\mathrm{h}}$ during the second half of the wet season (Fig. 10). The reduced solution enriched in alkalinity and base cations is partially exported towards the stream through the sandy network during the wet season. At the subsequent oxidation phase, oxidation reactions produce protons in the same proportion as the consumption during the reduction phase. Because part of the alkalinity has been evacuated from the system, the $\mathrm{pH}$ decreases and reaches values lower than those found at the beginning of the cycle. These changes are reflected on lysimeters $C_{i}, C_{j}$, and $C_{h}$ in horizon 4 (Fig. 12) on November $10^{\text {th }}$. On the other hand, since part of the displaced base cations were removed with the reduced solution, and because exchangeable $\mathrm{Fe}$ (II) shifts to $\mathrm{Fe}$ (III) and precipitates as iron oxides, free sites are available on the exchange capacity. Base cations are often low in soil solutions since they adsorb onto complexes and their amounts drop in the soil solution (See Fig. 10 on November $10^{\text {th }}$ ). However this adsorption does not compensate for the desorption that occurs during the reduced phase. Thus, the saturation rate of the exchange capacity decreases and protonation rate increases (see table 1, horizon 4). The $\mathrm{pH}$ values of the samples collected in the lysimeters are only moderately low (the minimum value recorded was 5.4), but they represent a large volume of soil solution, reflecting lower $\mathrm{pH}$ values at the very local scale thus creating harsh weathering environments (Laudelou and Eeckman, 1958). The protonated clays are not stable as their crystalline structure octahedral layers are penetrated by $\mathrm{H}^{+}$and substitute for $\mathrm{Al}^{3+}$, which is released from the crystalline net and becomes adsorbed on the clay surface. Consequently, $\mathrm{Al}^{3+}$ can no longer link the tetrahedral layers thus, these dislodge and silica is released in the system (Brinkman, 1970; Van Bremen et al., 1983; Van Breemen, 1988). These findings are shown in data collected on November $10^{\text {th }}$ (Fig. 10). Iron oxides precipitate locally, i.e., in the vicinity of the protonated clay, at the edge of the loamy sand network (Filizola and Boulet, 1995).

REE patterns in the solutions from the lysimeter located in horizon 4, in particular the increasing negative Ce-anomaly $\left(\mathrm{Ce} / \mathrm{Ce}^{*}\right.$ about 0.26$)$ with respect to the clay matrix groundmass $\left(\mathrm{Ce} / \mathrm{Ce}^{*}\right.$ about 0.88 ), confirm the influence of redox reactions in acquisition of solution chemistry (Table 6). A fraction of $\mathrm{Ce}^{3+}$, released upon the dissolution of Ce-bearing clay minerals, can be oxidized to $\mathrm{Ce}^{4+}$ by secondary Fe/Mn-oxides and hydroxides. Once oxidized, Ce mobility decreases due to either its strong sorption onto Fe/Mn-oxides and hydroxides (Koppi et al., 1996) or its possible precipitation as cerianite $\left(\mathrm{CeO}_{2}\right)$ (Braun et al., 1998, Dia et al., 2000; Laveuf and Cornu, 2009). These processes generate a positive Ce anomaly in REE pattern in the solid phase with $\mathrm{Fe} / \mathrm{Mn}$ - 
oxides and hydroxides (not analysed in our study) and lead to a negative Ce anomaly in the flowing solution (Tyler, 2004).

Given our findings from monitoring soil chemistry, we postulate that the texture contrast in horizon 4 arises from ongoing ferrolysis. Thus, one must be cautious in their findings as only 3-years of monitoring was not sufficient to observe all potential scenarios in rainfall distribution along the season. However, from this set of data, we can postulate that the maximum weathering conditions are occurring at the end of the rainy season, as reflected in low base values, low $\mathrm{pH}$ and increasing silica in the lysimeters located in the ferrolysed horizon 4. The findings suggest that rainy events occurring later than usual, for example in November or even December, may have a strong contribution to the elimination of the by-products of the clay weathering. On the other hand, our data show no lag period between the cessation of saturation and the transition from reducing to oxidizing conditions. Therefore, the development of two ferrolysis cycles can occur when the rainy season is temporarily interrupted by a significant dry period (see for example Eh-pH changes during rainy season 2006, Fig. 12), thus, increasing significantly the contribution of the ferrolysis process to the chemistry of the local rivers.

At the landscape scale: Although bleaching of the soil cover is observed, the monitoring of the redox potential showed that ferrolysis could not occur along the depression. Despite the long saturation period, the redox potential did not drop below threshold values of $\mathrm{Fe}^{2+}$ appearance. The water alternately flows in the soil cover, where the redox potential could decrease, and at the topsoil within the ponds where more oxidized conditions are prevail (Fig. 5). This water pathway prevents the low redox conditions necessary for ferrolysis development.

Conversely, the sandy loam texture observed in horizons 5, 6 and 7 cannot result from deposition. This information is derived from the wedge-shaped aggregates observed at the bottom part of horizon 6 . These could not have developed within the sandy loam material observed at present, but within swelling clay with vertic properties like those observed in horizon 2 (Fig. 3e and 3f). During bleaching and textural changes that progressively transform horizon 2 into 6 , the vertic structure is thought to disappear. The presence of the cemented wedge-shaped aggregates at the top of horizon 6 suggests that both, cementation by amorphous silica and bleaching for removing the clay fraction have simultaneously occurred. The silica accumulates in and around aggregates, where it cements quartz grains and remaining clay particles (Fig. 3d). Continued development leads to the formation of well-developed duripan ( $\mathrm{Si}$ cementation) preserving the former structure with wedge-shaped aggregates. Such developments are observed in the sandy loam horizon 6 (Fig. 3b). 
The ferrolysis process is possible only in an open system since it requires the evacuation of the reduced solution. At the scale of the landscape, ferrolysis is favoured by the presence of the streambed that has chiselled the soil cover. We observed that the ferrolysed horizons do not occur at the centre, but at the border of the black soil area. However, the process is less pronounced at the immediate downslope border since this part of the soil cover receives reduced soil solutions carrying the by-products of the ferrolysis process that occurred at the upslope. The alkaline solution is rich in base cations and partly offsets the loss of bases and alkalinity occurring at the downslope, thereby reducing the effect of the ferrolysis.

The development of the sandy network through ferrolysis favours the elimination of the reduced solution, which in its turn increases the weathering that favours lower $\mathrm{pH}$. Therefore, an "autocatalysis" of the ferrolysis process is expected.

Timing the onset of ferrolysis: The seasonal nature of rainfall, and maximum weathering conditions occurring at the end of the rainy season, are contributing factors that impair the removal of ferrolysis by-products (mainly silica, alkalinity, $\mathrm{Ca}$ and $\mathrm{Mg}$ ) removed towards the stream. They are transported downslope and accumulate in the soil cover forming calcareous nodules along the slope and silica cements further downslope.

Calcareous nodules are frequently observed in Vertisols in South India, although they have been studied mainly in Vertisols developed in the alluvium of weathering Deccan basalt (Pal et al., 2000, Srivastava et al., 2002), and in alfisols under semi-arid climate (Durand et al., 2007). In our case, several considerations allow us to attribute the occurrence of calcareous nodules to the ferrolysis process. These include: 1 . The tongue-shaped volume with carbonates is extends downslope to the ferrolysed area; 2. It is fringing the streambed, which allows the evacuation of the reduced solutions and the development of the ferrolysis; 3. The ${ }^{14} \mathrm{C}$ ages of the carbonates along $\mathrm{T}$ suggest a progression towards upslope, and are in agreement with a flow of the alkaline solutions from the ferrolysed area towards the stream; 4. The third axis of the PCA discriminated alkaline extracts located at the upper part of the volume with carbonate, suggests its present day progression; 5 . The soil solutions collected in the lysimeters reach $\left(C_{h}\right)$ or are close to saturation $\left(C_{i}\right.$ and $\left.C_{j}\right)$ with respect to calcite; 6 . The solutions flowing in the ferrolysed network show a significant negative cerium anomaly that is also observed in the carbonate phase of the nodules.

It is noteworthy that an environment favouring the breakdown of the 2:1 and even 1:1 clay minerals might cause the formation of $\mathrm{CaCO}_{3}$. Indeed, both processes occur along the same soil sequence and overlap at the midslope, as illustrated in Fig. 4. This apparent contradiction can be explained considering that they occur at a different time and place. The aggressiveness of the soil solution with respect to clay minerals is maximal at the end of the rainy season and has a local effect seen at 
the contact between the sandy network and the clay matrix groundmass. Moreover $\mathrm{CaCO}_{3}$ formation occurs during the dry season, while the clay matrix groundmass impregnated with the alkaline soil solution is drying. From these considerations, we postulate that carbonate occurrences at the study site are directly related to ferrolysis.

Therefore, the distribution of ${ }^{14} \mathrm{C}$ carbonates ages allows us to verify that the ferrolysis started only about $2 \mathrm{kyr}$ ago at our study site A (Fig. 1) and about $4.2 \mathrm{kyr}$ ago at the site B, which is located $500 \mathrm{~m}$ downstream from site A.

Application to the assessment of physical erosion rate at the watershed scale: The presence of a drainage network was essential for ferrolysis. We previously concluded that both cementation by amorphous silica and bleaching have occurred simultaneously in the depression along transect $\mathrm{S}$. Because amorphous silica is a by-product of ferrolysis, it suggests that ferrolysis began in the early stage of the streambed incision. This is in agreement with the occurrence of silica-cemented horizons at different spots along the main streambed of the watershed (Barbiero et al., 2007). Therefore, the oldest ${ }^{14} \mathrm{C}$ radiocarbon dating of calcareous nodules located in the context of ferrolysis (identified from the presence of horizon 4 in the black soil profile), gave an indirect dating of the streambed incision and the rejuvenation of the valley bottom. By extrapolating the dating periods obtained on spots $\mathrm{A}$ and spot B, where ferrolysis was identified, we assume that the incision of the streambed started about $5 \mathrm{kyr}$ BP at the outlet of the watershed. A rough estimate of the incised volume (length, width and depth of the incision), was calculated during the initial survey of the area, resulting in approximately $68100 \mathrm{~m}^{3}$. In addition, 3 erosion types (rotational slips, seepage erosion and recurrent combination of earth flow and sliding), which have been induced by the incision, were quantified in a previous study (Barbiero et al., 2007) giving a total volume of about $30000 \mathrm{~m}^{3}$. The total eroded volume $\left(98100 \mathrm{~m}^{3}\right)$, relates to the total area of the watershed $\left(4.1 \mathrm{~km}^{2}\right)$ and along a period of $5 \mathrm{kyr}$ denotes a physical erosion rate of about $4.810^{-3} \mathrm{~m} / \mathrm{kyr}$. This value is in agreement with the recent results presented by Gunnell et al. (2007), who estimated the denudation rate (physical erosion + chemical weathering), which is controlled by fluvial incision rates, at about $13.6 \pm 2.910^{-3} \mathrm{~m} / \mathrm{kyr}$ into the plateau surface of the South Indian Western Ghats (Table 2 in Gunnell et al, 2007).

\section{Conclusions and future directions:}

This study reveals the occurrence of a ferrolysis process in some spots of black soils (Vertisols and Vertic Intergrades) located in the vicinity of the drainage in sub-humid south India. The most aggressive conditions responsible for the breakdown of 2:1 and 1:1 clay minerals occurred at the end of the rainy season, just before the disappearance of the perched watertable at the base of the 
black soil system. Ferrolysis by-products were mainly silica, alkalinity, $\mathrm{Ca}$ and $\mathrm{Mg}$ that lead to the formation of calcareous nodules and duripans downslope the ferrolysed area. Ferrolysis, which requires an open system to develop, was induced by recent incisions by streambeds and revived valley bottoms. Therefore, dating of $\mathrm{CaCO}_{3}$ nodules, which are established by-products of the ferrolysis process due of their arrangement in the soil system, allowed us to propose an indirect dating of the streambed incision. At our study site, the incision likely occurred 2000 years BP, whereas we initially assume it started about 5000 years BP at the outlet of the Mule-Hole watershed. This information, together with the assessment of the volume of soil exported through the recent reactivation of erosion, permit for an estimate of the physical erosion rate at the watershed scale. This estimate is roughly $4.810^{-3} \mathrm{~m} / \mathrm{kyr}$ for the last $5 \mathrm{kyr}$. In further studies, this result should be compared to the present day exportation of sediments at the outlet and also compared to the assessment of the denudation rate (physical erosion + chemical weathering) obtained using cosmogenic nuclides (Gunnell et al., 2007). Because the streambed incision is a regional process and ferrolysis is likely occurring at other spots, this type of study should be applied for the assessment of the physical erosion rate at a wider scale in the Kabini upper basin. Finally, future work will focus on the impact of ferrolysis on the chemistry of the stream water at the watershed scale through hydrograph deconvolution.

\section{Acknowledgments}

This study was supported through the research project "Kabini river basin" of ORE-BVET Observatoire de Recherche en Environnement - Bassin Versant Expérimentaux Tropicaux, (www.orebvet.fr), the French national programs "ECCO-PNRH" and "ACI-Eau" funded by IRD/INSU/CNRS, the Indo-French Centre for the Promotion of Advanced Research (CEFIPRAIFCPAR project WA-3000). We thank H. Lissner for significant field and laboratory contribution and the Karnataka Forest Department for providing the access to the site.

\section{References}

Agarwala, V.P., 1985. Forests in India, Environmental and production frontiers. IBH Publications, New Delhi and Oxford, pp. 1-344.

Balpande, S.S., Deshpande, S.B., Pal, D.K., 1996. Factors and processes of soil degradation in Vertisols of the Purna Valley, Maharashtra, India. Land Degradation \& Development 7, $313-324$. 
Barbiero L., Ould Mohamedou A., Roger L., Furian S., Aventurier A., Rémy J.C., Marlet S., 2005. The origin of Vertisols and their relationship to Acid Sulfate Soils in the Senegal Valley. Catena 59, 93-116.

Barbiero, L., Parate, H.R., Descloitres, M., Bost, A., Furian, S., Mohan Kumar, M.S., Kumar, C., Braun, J.J., 2007. Using a structural approach to identify relationships between soil and erosion in a semi-humid forested area, South India. Catena 70, 313-329.

Biscaye, P.E., 1965. Mineralogy and sedimentation of a recent deep-sea clay in the Atlantic Ocean, adjacent seas and oceans. Geological Society of America Bulletin 76, 803-832.

Boivin, P., Saejiew, A., Grunberger, O., Arunin, S., 2004. Formation of soils with contrasting textures by translocation of clay rather than ferrolysis in flooded rice field in Northeast Thailand. European Journal of Soil Science 55, 713-724.

Braun, J.J., Viers, J., Dupré, B., Polvé, M., Ndam, J., Muller, J.P., 1998. Solid/liquid REE fractionation in the lateritic system of Goyoum, East Cameroon: The implication for the present dynamics of the soil covers of the humid tropical regions, Geochimica Cosmochimica Acta 62, 273-299.

Braun, J.J., Ruiz, L., Riotte, J., Mohan Kumar, M.S., Murari, V., Sekhar, M., Barbiero, L., Descloitres, M., Bost, A., Dupré, B., Lagane, C., 2005. Chemical and physical weathering in the Kabini River Basin, South India. Goldschmidt Conference Abstracts 2005, The Earth's Weathering Engine. Geochimica et Cosmochimica Acta 69, Supplement 1, A691.

Braun, JJ, Descloitres, M., Riotte, J., Fleury, S., Barbiero, L., Boeglin, J.L., Violette, A., Lacarce, E., Ruiz, L., Sekhar, M., Mohan Kumar, M.S., Subramanian, S., Dupré, B., 2009. Regolith mass balance inferred from combined mineralogical, geochemical and geophysical studies: Mule Hole gneissic watershed, South India. Geochimica Cosmochimica Acta 73, 935-961.

Boulet, R., Chauvel, A., Humbel, F.X. and Lucas, Y., 1982. Analyse structurale et cartographie en pédologie. I - Les études de toposéquences et principaux apports à la connaissance des sols. II - Une méthode d'analyse prenant en compte l'analyse tridimensionnelle des couvertures pédologiques. III - Passage de la phase analytique à une cartographie générale synthétique. Cahier ORSTOM Séries Pédologie 19, 309-351.

Bourgeon, G., 1991. Les “sols rouges” de l'Inde péninsulaire méridionale: Pédogenèse fersiallitique sur socle cristallin en milieu tropical. Doctorat Thesis, Université Paris VI, France.

Bourgeon, G. and Pedro, G., 1992. Rôle majeur du drainage climatique dans la différentiation altéritique et pédologique des sols des régions chaudes. Comptes Rendus de l'Académie des Sciences Paris 314, 717-725.

Brammer, H., Brinkman, R., 1977. Surface water gley soils in Bangladesh. Environment, landforms and soil morphology. Geoderma 17, 91-109. 
Brinkman, R. 1970. Ferrolysis, a hydromorphic soil forming process. Geoderma 3, 199-206.

Brinkman, R. 1977. Problem hydromorphic soils in north-east Thailand. 2. Physical and chemical aspects, mineralogy and genesis. Netherlands Journal of Agricultural Science 25, 170-181.

Brinkman, R. 1979. Ferrolysis, a soil forming process in hydromorphic conditions. Doctoral thesis, Centre for Agricultural Publishing and Documentation, Wageningen. Agricultural Research Reports 887.

Brinkman, R., Jongmans, A.G., Miedema, R, Maaskant, P., 1973. Clay decomposition in seasonally wet, acid soils: micromorphological, chemical and mineralogical evidence from individual argillans. Geoderma 10, 159-270.

Brinkman, R., Jongmans, A.G., Miedema, R, 1977. Problem hydromorphic soil in north-east Thailand. 1-Environment and soil morphology. Netherlands Journal of Agricultural Science $25,108-125$.

Brinkman, R., Wieleman, P.J., 1977. Problem hydromorphic soil in north-east Thailand. 3-Saline acid conditions, reclamation, improvement and management. Netherlands Journal of Agricultural Science 25, 263-277.

Christidis, G.E., and Eberl, D. D., 2003. Determination of layer-charge characteristics of smectites. Clays and Clay Minerals 51, 644-655.

Descloitres, M., Ruiz, L., Sekhar, M., Legchenko, A., Braun, J. J., Mohan Kumar, M.S., Subramanian, S., 2008. Characterization of seasonal local recharge using Electrical Resistivity Tomography and Magnetic Resonance Sounding. Hydrological Processes 22, 384-394.

Dia, A., Gruau, G., Olivié-Lauquet, G., Riou, C., Molénat J., Curmi, P., 2000. The distribution of rare earth elements in groundwaters: assessing the role of source-rock composition, redox changes and colloidal particles. Geochimica Cosmochimica Acta 64, 4131-4151.

Driese, S.G., Nordt, L.C., Lynn, W.C., Stiles, C.A., Mora, C.I., Wilding, L.P. 2005. Distinguishing climate in the soil record using chemical trends in a Vertisol climosequence from the Texas Coast Prairie, and application to interpreting Paleozoic paleosols in the Appalachian Basin. Journal of Sedimentary Research 75:340-353.

Durand, N., Gunnel, Y., Curmi, P., Masood Ahmad, S., 2007. Pedogenic carbonates on Precambrian silicate rocks in South India: Origin and paleoclimatic significance. Quaternary International 162-163, 35-49.

Eaqub, M., Blume H.P., 1982. Genesis of a So-called Ferrolysed Soil of Bangladesh. Zeitschrift für Pflanzenernährung und Bodenkunde 145, 470 - 482. 
Favre, F., Tessier, D., Abdelmoula, M., Genin, J., Gates, W.P., Boivin, P., 2002. Iron reduction and changes in cation exchange capacity in intermittently waterlogged soil. European Journal of Soil Science 53, 175-184.

Filizola, H. and Boulet, R., 1995. Formation géochimique d'horizons stratiformes dans un sédiment altéré : Relais entre néoformation de kaolinite et ferrolyse. Bassin de Taubaté, Brésil. Comptes Rendus de l'Académie des Sciences Paris 320, 1087-1093.

Fritsch, E., Peterschmitt, E. and Herbillon, A.J., 1992. A structural approach to the regolith: Identification of structures, analysis of structural relationships and interpretations. Sciences Géologiques Bulletin 45, 77-97.

Gunnell, Y., 2000. The characterization of steady state in earth surface systems: finding from the gradient modelling of an Indian climosequence. Geomorphology 35, 11-20.

Gunnell, Y., Bourgeon, G., 1997. Soils and climatic geomorphology on the Karnataka Plateau, peninsular India. Catena 29, 239-262.

Gunnell, Y., Braucher, R., Bourles, D. and Andre, G., 2007. Quantitative and qualitative insights into bedrock landform erosion on the South Indian craton using cosmogenic nuclides and apatite fission tracks. Geological Society of America Bulletin 119, 576-585.

Hendrickx, J.M.H., Baerends, B., Raza, Z.I., Sadig, M. and Chaudhry, M.A., 1992. Soil salinity assessment by electromagnetic induction of irrigated land. Soil Science Society of America Journal 56, 1933-1941.

Hobson, W. A. and R. A. Dahlgren. 1998. A Quantitative Study of Pedogenesis in California Vernal Pool Wetlands. p. 107-127. In: Quantifying Soil Hydromorphology. SSSA Special Publication No. 54. SSSA, Madison, Wisconsin.

IUSS-ISRIC-FAO, 2006. World reference base for soil resources. A framework for international classification, correlation and communication. World Soil Resources Reports 103, 128 p.

Jacks, G., Sharma, V.P., 1995. Geochemistry of calcic horizons in relation to hillslope processes, Southern India. Geoderma 67, 203-215.

Kahle, M., Kleber, M., Jahn, R., 2002. Review of XRD-based quantitative analyses of clay minerals in soil: the suitability of mineral intensity factors. Geoderma 109, 191- 205.

Koppi, A.J., Edis, R., Field, D.J., Geering, H.R., Klessa, D.A., Cockayne, D.J.H., 1996. Rare earth element trends and cerium-uranium-manganese associations in weathered rock from Koongarra, Northern Territory, Australia. Geochimica Cosmochimica Acta 60,1695-1707.

Lacarce, E., 2005. Processus pédogénétiques et évolutions minéralogiques à l'origine des associations sol rouge/sol noir sur le complexe gneissique de la zone de transition climatique de l'Inde péninsulaire. Ph.D. Thesis University Paris 6, 180 p. 
Laveuf, C., Cornu, S., 2009. A review on the potentiality of Rare Earth Elements to trace pedogenetic processes. Geoderma 154, 1-12.

Laudelou, H., Eeckman, J.P., 1958. La stabilité chimique des suspensions d'argile saturées par l'ion hydrogène. International Society of Soil Science Transactions II, IV Commission, Hamburg 2, 193- 199.

Legchenko, A., Descloitres, M., Bost, A., Ruiz, L., Reddy, M., Girard, J-F., Sekhar, M., Mohan Kumar, M. S. and Braun, J. J. (2006) Resolution of MR Soundings applied to the characterization of hard rock aquifers, Journal of Ground Water 44, 547-554.

Maître, V., 1991. Protocole d'extraction, de conservation et de filtration des eaux libres du sol. Science du sol 29, 71-76.

Maréchal, J-C., Murari, R.R.V., Riotte, J., Vouillamoz, J-M., Kumar, M.S.M., Ruiz, L., Sekhar, M., Braun, J-J., 2009. Indirect and direct recharges in a tropical forested watershed: Mule Hole, India, Journal of Hydrology 364, 272-284.

McNeill, J.D., 1980. Electromagnetic terrain conductivity measurement at low induction numbers. Technical Note TN-6, Geonics Ltd, Ontario, Canada.

Montagne, D., Cornu, S., Le Forestier, L., Hardy, M., Josière, O., Caner, L., Cousin, I., 2008. Impact of drainage on soil-forming mechanisms in a French Albeluvisol: Input of mineralogical data in mass-balance modelling. Geoderma 145, 426-438.

Moyen, J.F., Martin, H. and Jayananda, M., 2001. Multi-element geochemical modelling of crustmantle interactions during late-Archean crustal growth: the Closepet Granite (South India). Precambrian Research 112, 87-105.

Murthy, R.S., Hirekerur, L.R., Deshpande, S.B., Venkat Rao, B.V., 1982. Benchmark Soils of India. National Bureau of Soil Survey and Land Use Planning, Nagpur, India.

Nordt, L.C., Wilding, L.P., Lynn W.C., Crawford, C.C., 2004. Vertisol genesis in a humid climate of the coastal plain of Texas, U.S.A. Geoderma 122, 83-102.

O’Geen A.T., Hobson, W.A., Dahlgren, R.A., Kelley, D.B., 2008. Evaluation of soil properties and hydric soil indicators for Vernal Pool catena in California. Soil Science Society of America Journal 72, 727-740.

Pal, D.K., Deshpande, S.B., 1987. Genesis of clay minerals in a red and black complex soils of southern India. Clay Research 6, 6-13.

Pal, D.K., Dasog, G.S., Vadivelu, S., Ahuja, R.L., Bhattacharyya, T., 2000. Secondary calcium carbonate in soils of arid and semi-arid regions of India. In Global Climate Change and Pedogenic Carbonates, Lal, R., Kimble, J.M., Eswaran, H., Stewart, B.A. (eds). Lewis Publishers: Boca Raton, FL; 149-185. 
Parate, R.P. , Mohan Kumar, M.S., Descloitres, M., Barbiero, L., Ruiz, L., Braun, J.J., Sekhar, M., Kumar, C., 2009. Comparison of electrical resistivity by geophysical method and neutron probe logging for soil moisture monitoring in forested watershed. Current Sciences, submitted.

Parkhurst, D.L., 1995. User's guide to PHREEQC-A computer program for speciation, reactionpath, advective-transport, and inverse geochemical calculations. Water-Resources Investigation Report 95-4227. U.S. Geological Survey, Lakewood CO.

Pascal, J.P., 1982. Forest map of South India, 1/250000 scale, sheet Mercara-Mysore. Travaux Section Scientifique et Technique Institut Français de Pondichéry, hors série 18a.

Radhakrishna, B.P., Vaidyanadhan, R., 1994. Black soils of Karnataka. In: Radhakrishna, B.P., Vaidyanadhan, R. (Eds.), Geology of Karnataka. Geological Society of India, Bangalore, pp. 239-251.

Ruiz, L., Varma, M.R.R., Mohan Kumar, M.S., Sekhar, M., Maréchal, J.C., Descloitres, M., Riotte, J., Kumar, S., Kumar, C., Braun, J.J., 2010. Water balance modelling in a tropical watershed under deciduous forest (Mule Hole, India): Regolith matric storage buffers the groundwater recharge process. Journal of Hydrology 380, 460-472.

Sehgal, J. and Mandal, D.K., 1995. Soil-climatic environments in India. Bulletin No. 58, National Bureau of Soil Survey and Land Use Planning, Nagpur, India.

Schaefer, C.E.R., Ker, J.C., Gilkes, R.J., Campos, J.C., da Costa, L.M., Saadi, A., 2002. Pedogenesis on the uplands of the Diamantina Plateau, Minas Gerais, Brazil: a chemical and micropedological study. Geoderma 107, 243-269.

Shadakshara Swamy, N., Jayananda, M., and Janardhan, A. S., 1995. Geochemistry of Gundlupet gneisses, Southern Karnataka: a 2.5 Ga old reworked sialic crust. In: Yoshida, M., Santosh, M., and Rao, A. T. Eds.), India as a fragment of East Gondwana. Gondwana Research Group.

Shiva Prasad, C.R., Reddy, R.S., Sehgal, J. and Velayutham, M., 1998. Soils of Karnataka: Their kinds, distribution, characterization and interpretations for optimising land use. Publication No. 47, National Bureau of Soil Survey and Land Use Planning, Nagpur, India.

Singh, L.P., Parkash, B., Singhvi, A.K., 1998. Evolution of the Lower Gangetic Plain landforms and soils in West Bengal, India. Catena 33, 75-104.

Srivastava, P., Bhattacharyya, T., Pal, D.K., 2002. Significance of the formation of calcium carbonate minerals in the pedogenesis and management of cracking clay soils (Vertisols) of India. Clays and Clay Minerals 50, 111-126.

Tyler, G., 2004. Rare earth elements in soil and plant systems - a review. Plant and Soil 267, 191206. 
Vaidya P.H., Pal, D.K., 2002. Microtopography as a factor in the degradation of vertisols in central India. Land Degradation and Development 13, 429-445.

Van Breemen, N., 1988. Effects of seasonal redox processes involving iron on the chemistry ofpe riodically reduced soils. In: Iron in Soils and Clay Minerals (eds J.W. Stucki, B.A. Goodman \& U. Schwertmann), pp. 797-809. D. Reidel, Dordrecht.

Van Breemen, N., Mulder J. and Driscoll, C.T., 1983. Acidification and alkalinization of soils. Plant and Soil 75, 283-308.

Van Ranst, E. De Corninck, F., 2002. Evaluation of ferrolysis in soil formation. European Journal of Soil Science 53, 513-519.

Wilding, L.P., Tessier, D., 1988. Genesis of Vertisols: shrink-swell phenomena. In: L.P. Wilding and R. Puentes, Editors. Vertisols: Their Distribution, Properties, Classification, and Management, Texas A\&M Univ. Print. Center, College Station, TX (1988), pp. 23-57.

Wright, V.P., Vanstone, S.D., Robinson D., 1991. Ferrolysis in Arundian alluvial palaeosols: evidence of a shift in the early Carboniferous monsoonal system. Journal of the Geological Society $148,9-12$.

\section{Figure captions}

Fig. 1: Location map of the study site, Mule Hole watershed, South India. A and B are two areas where the ferrolysis process is identified (altitude in metres).

Fig. 2 : Study area, landscape morphology, toposequences and distribution of the lysimeters.

Fig. 3: a) Natural triangular-shaped ponds developing along the depression over silica cemented horizons (transect $\mathrm{S}$ and bottom part of transect $\mathrm{T}$ ); b) and c) Contrast between the loamy sand network and the clay matrix along transect T. (See also Fig 4 and 5 for location); d) SEM picture showing typical "silica flower" coatings in the cemented horizon of the depression; e) and f) detailed image of the profile in the depression (transect $\mathrm{S}$ and bottom part of transect $\mathrm{T}$ ) showing wedge-shaped aggregates preserved in the sandy loam material due to silica cementation (vertical and sub-horizontal cracks are indicated by arrows in picture d, knife is about $25 \mathrm{~cm}$ ).

Fig. 4 : Distribution of the main horizons along cross section $\mathrm{T}$, their concordance with ECm values, the distribution of ${ }^{14} \mathrm{C}$ dating on calcareous nodules, and, the development model for their occurrence. The circle denotes the middle slope where both destruction of 2:1 clay minerals and formation of $\mathrm{CaCO}_{3}$ occur.

Fig. 5 : Simplified soil layout along the depression (transect S) showing the distribution of silica cemented horizons. 
Fig. 6 : Variable and sample distributions on the first factorial plan of the PCA carried out on saturated extracts and lysimeters.

Fig. 7 : Variable and sample distributions on the first and second factorial plans of the PCA carried out on saturated extracts.

Fig. 8 : Distribution of the 3 main factorial axes along the transect T (PCA carried out on saturated extracts). Factorial axis 1, 2 and 3 explain $60.9 \%, 13.5 \%$ and $10.4 \%$ of the variance, respectively.

Fig. 9 : Variable and sample distributions on the first factorial plan of the PCA carried out on lysimeter samples.

Fig. 10. Monitoring the chemistry profile in lysimeters $C_{i}$ (closed symbols) and $C_{h}$ (open symbols) during the wet season of 2006. Note the changes occurring between November $8^{\text {th }}$ and $10^{\text {th }}$. Fig. 11 : Eh-pH monitoring along the depression (transect S) for 2005-, 2006- and 2007-wet seasons.

Fig. 12 : Eh-pH monitoring along the transect T for 2005-, 2006- and 2007-wet seasons.

Table captions:

Table 1: Chemical and mineralogical properties of selected samples

Table 2. Descriptive statistics of the major ions and silica for saturated extracts.

Table 3. Descriptive statistics of the major ions and silica for lysimeter samples.

Table 4: Singular values of the Principal Component Analysis (PCA) carried out on saturated extracts and on the following variable: major elements, $\mathrm{pH}$ and silica.

Table 5: Singular values of the Principal Component Analysis (PCA) carried out on lysimeter samples and on the following variable: major elements, $\mathrm{pH}$ and silica.

Table 6: Mean values of the cerium anomaly $\mathrm{Ce} / \mathrm{Ce}^{*}$ in the black soil, solutions in lysimeters and calcareous nodules (data normalized to the local peninsular gneiss) 


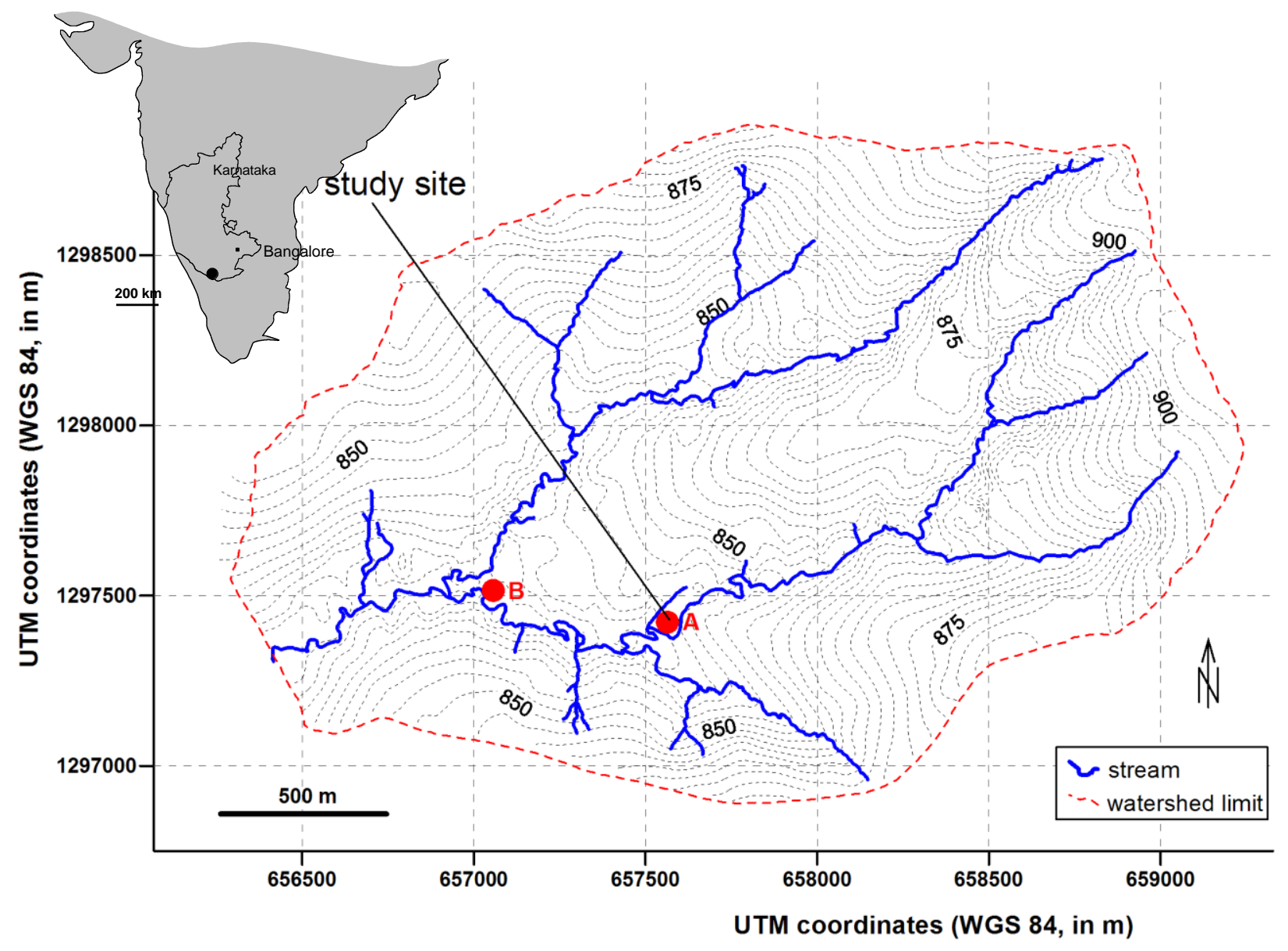

Fig. 1: Location map of the study site, Mule Hole watershed, South India. A and B are two areas where the ferrolysis process is identified (altitude in metres). 


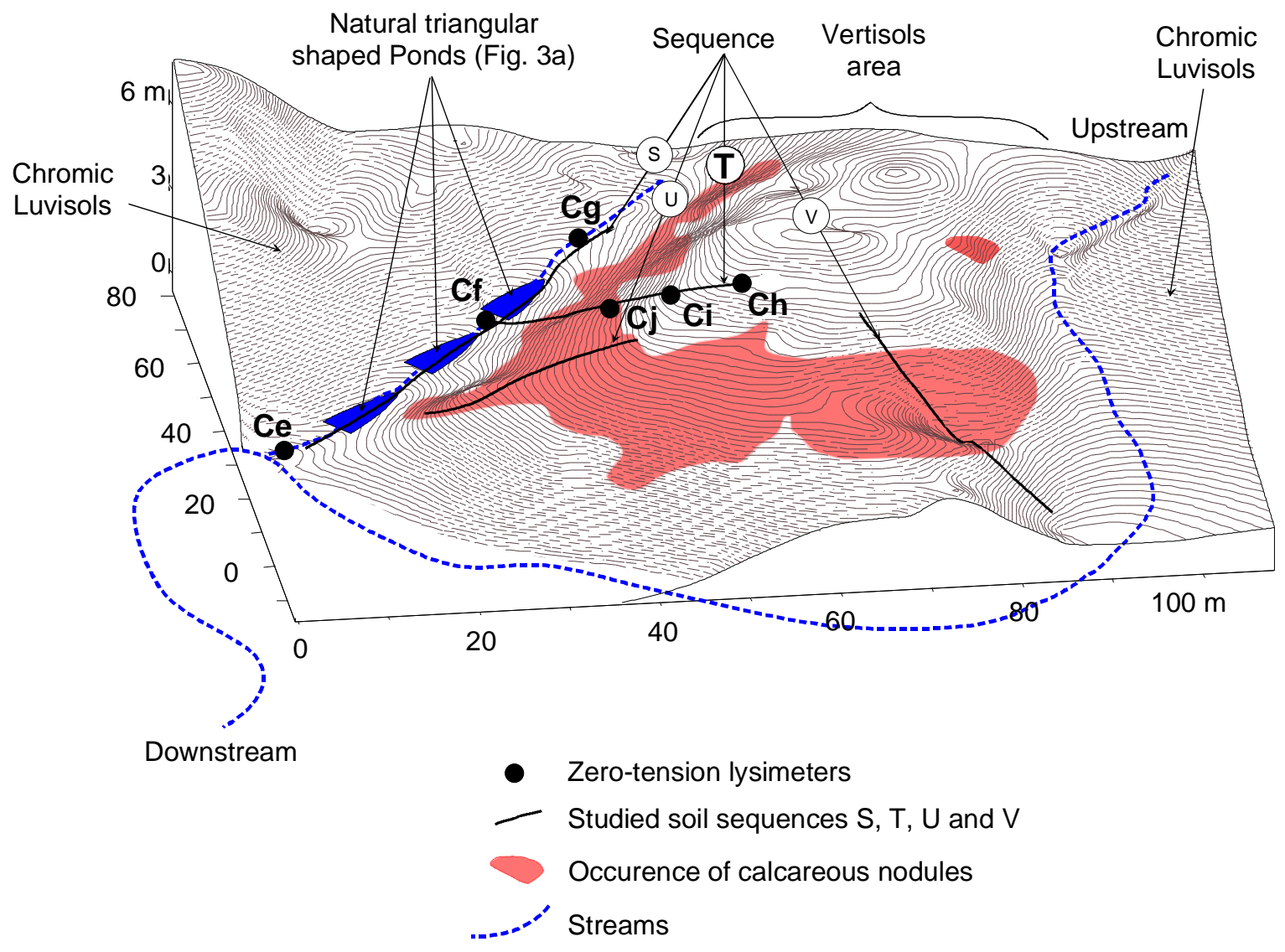

Fig. 2 : Study area, landscape morphology, toposequences and distribution of the lysimeters. 

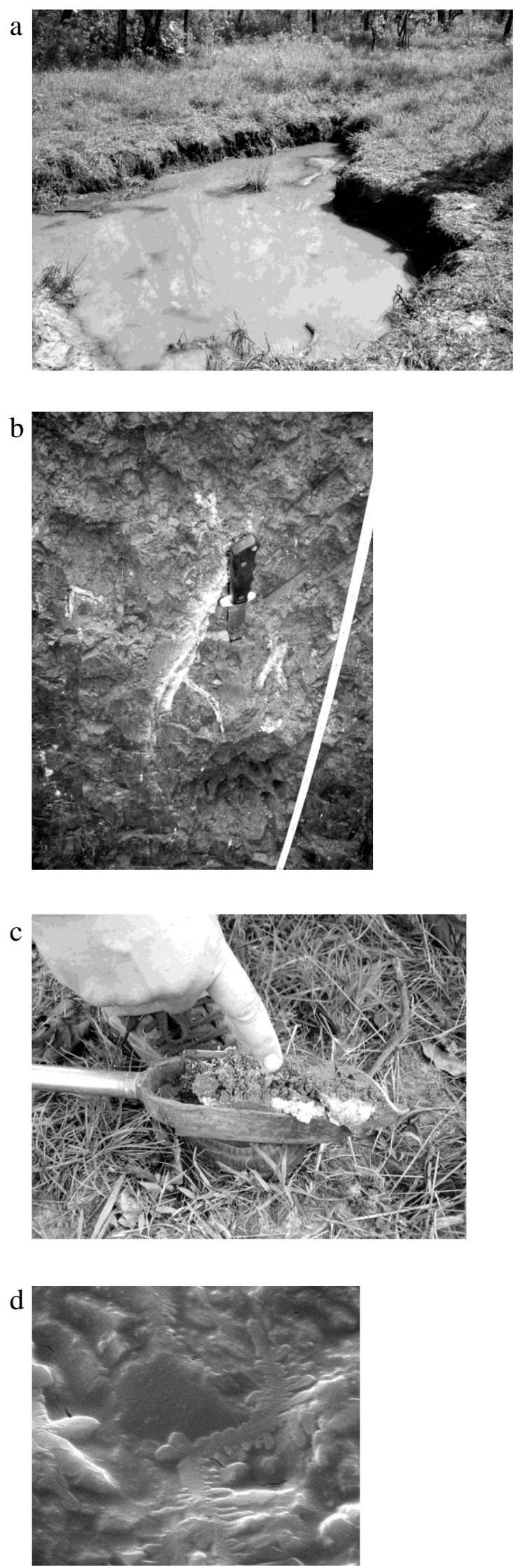

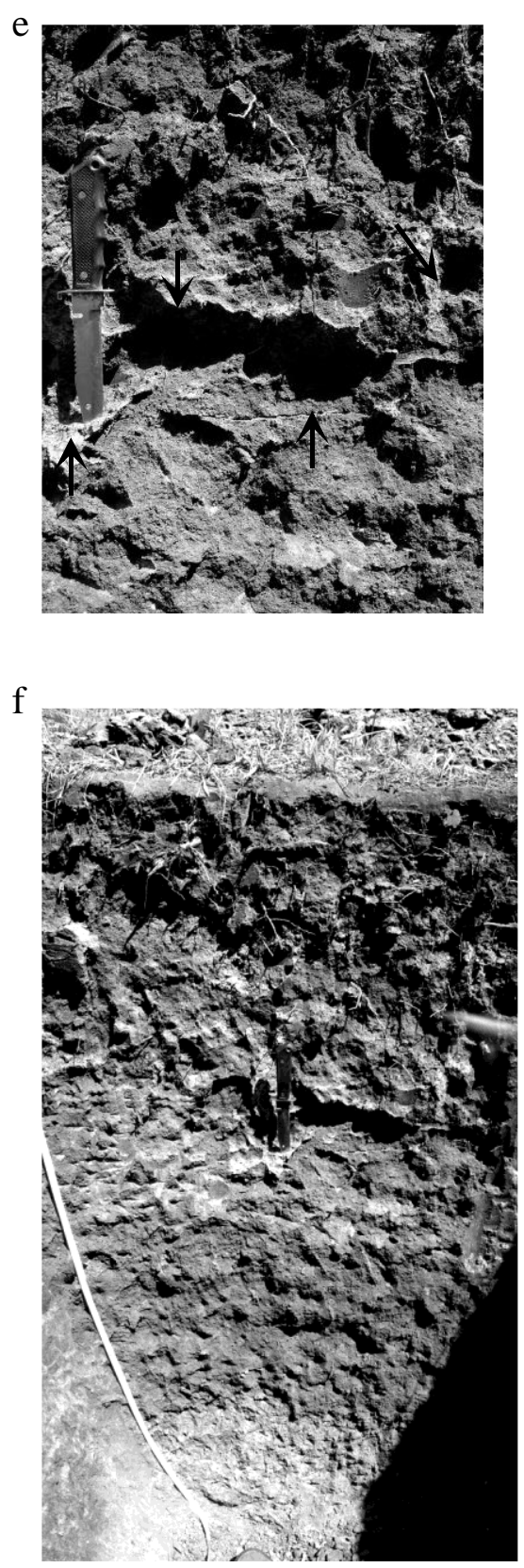

Fig. 3: a) Natural triangular-shaped ponds developing along the depression over silica cemented horizons (transect $\mathrm{S}$ and bottom part of transect $\mathrm{T}$ ); b) and c) Contrast between the loamy sand network and the clay matrix along transect T. (See also Fig 4 and 5 for location); d) SEM picture showing typical "silica flower" coatings in the cemented horizon of the depression; e) and f) detailed image of the profile in the depression (transect $\mathrm{S}$ and bottom part of transect $\mathrm{T}$ ) showing wedge-shaped aggregates preserved in the sandy loam material due to silica cementation (vertical and sub-horizontal cracks are indicated by arrows in picture d, knife is about $25 \mathrm{~cm}$ ). 


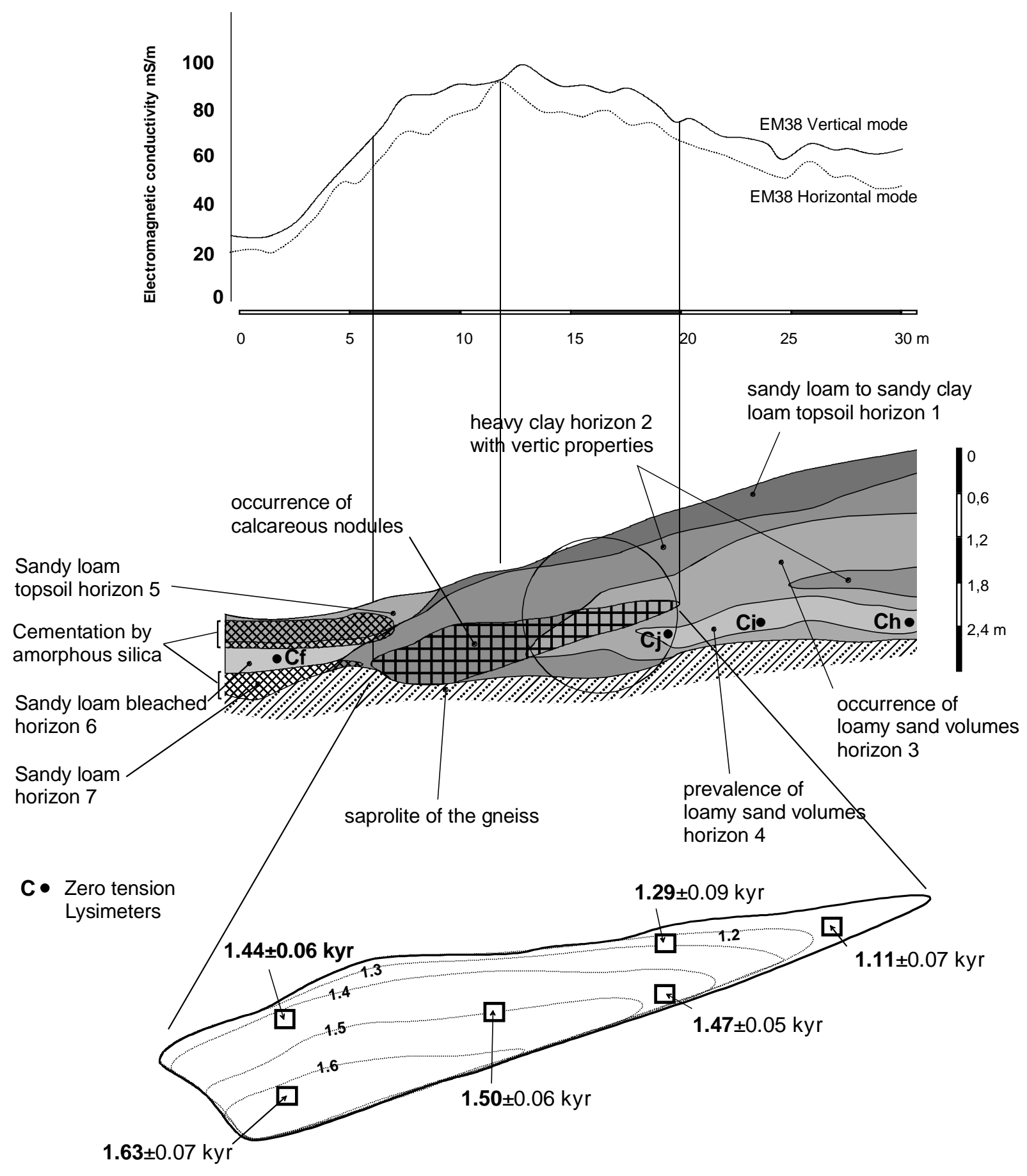

Fig. 4 : Distribution of the main horizons along cross section $\mathrm{T}$, their concordance with ECm values, the distribution of ${ }^{14} \mathrm{C}$ dating on calcareous nodules, and, the development model for their occurrence. The circle denotes the middle slope where both destruction of 2:1 clay minerals and formation of $\mathrm{CaCO}_{3}$ occur. 


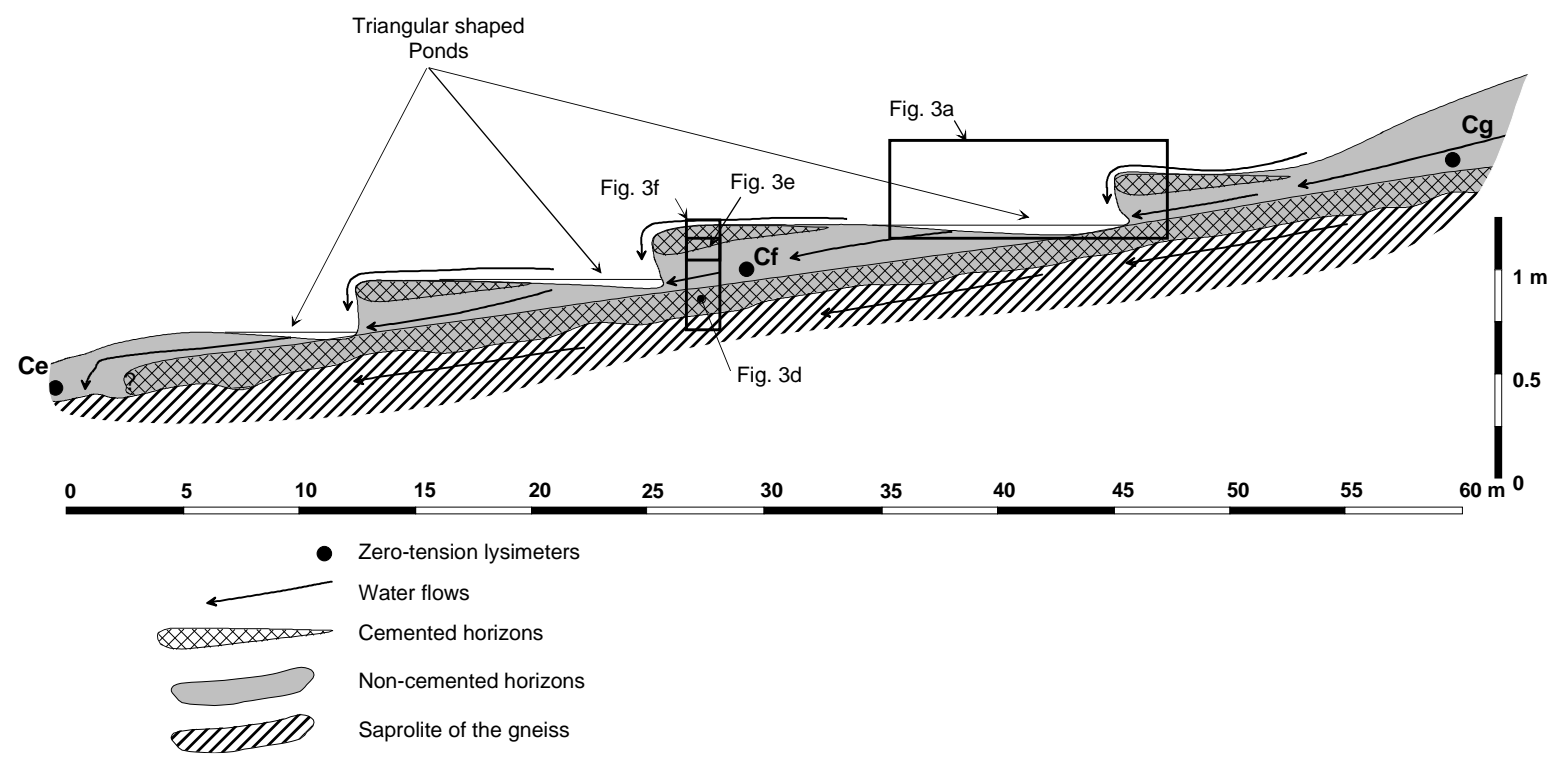

Fig. 5 : Simplified soil layout along the depression (transect $S$ ) showing the distribution of silica cemented horizons. 

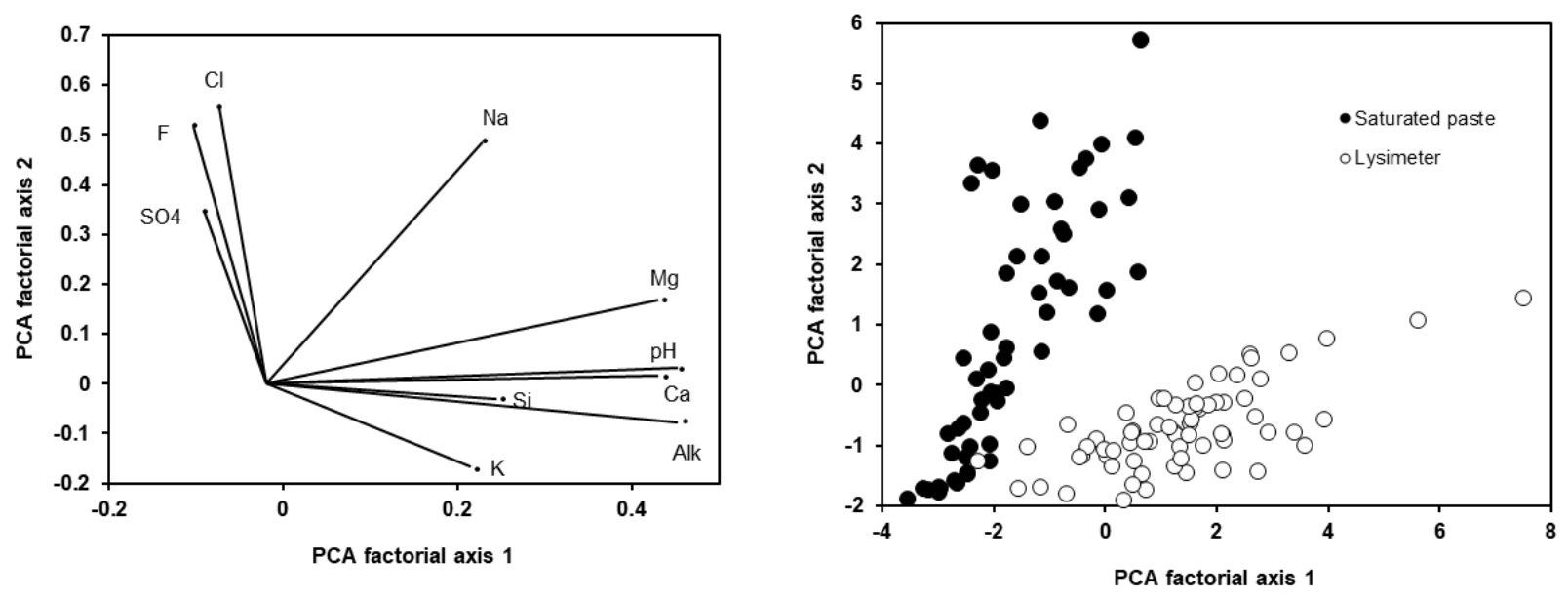

Fig. 6 : Variable and sample distributions on the first factorial plan of the PCA carried out on saturated extracts and lysimeters.
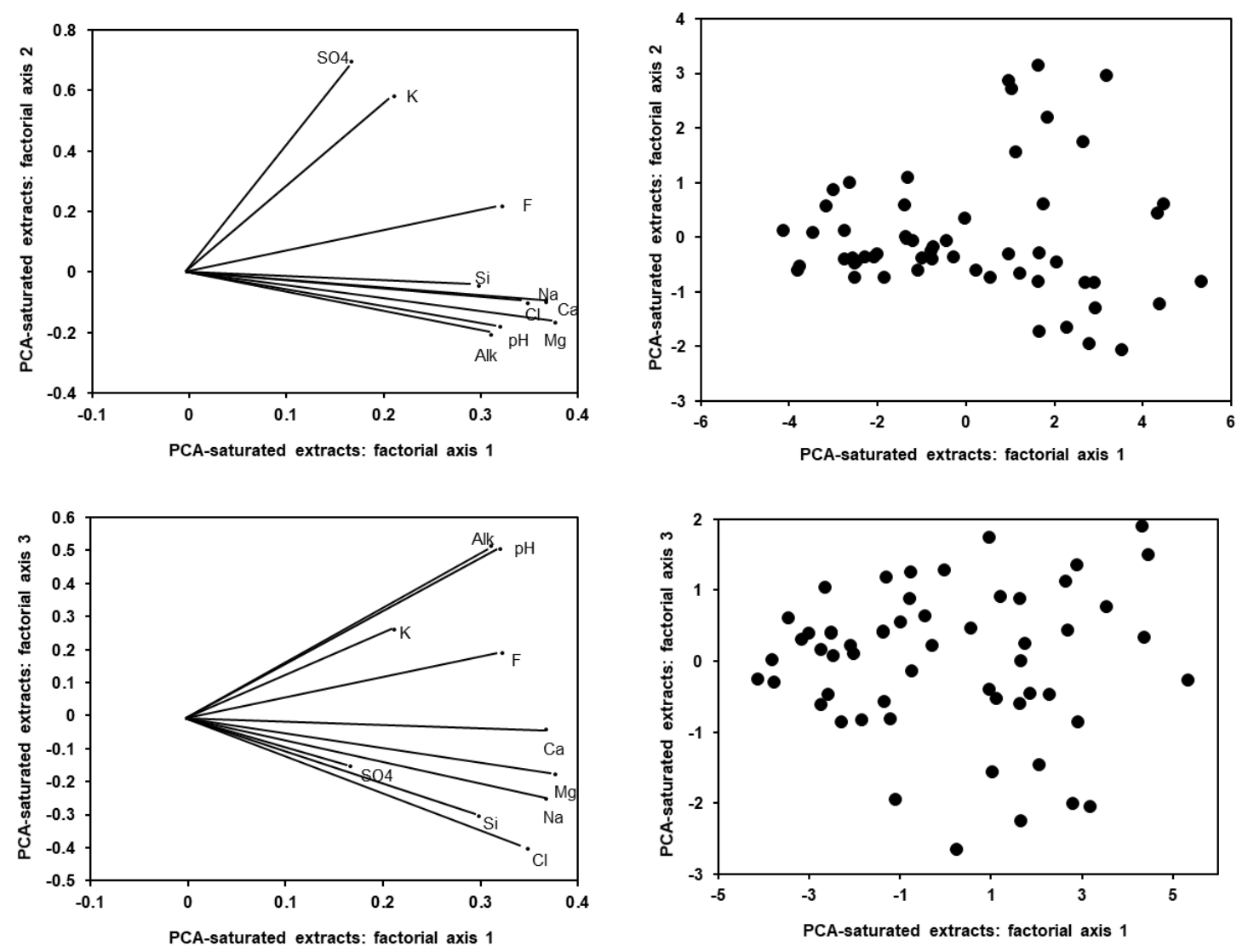

Fig. 7 : Variable and sample distributions on the first and second factorial plans of the PCA carried out on saturated extracts. 


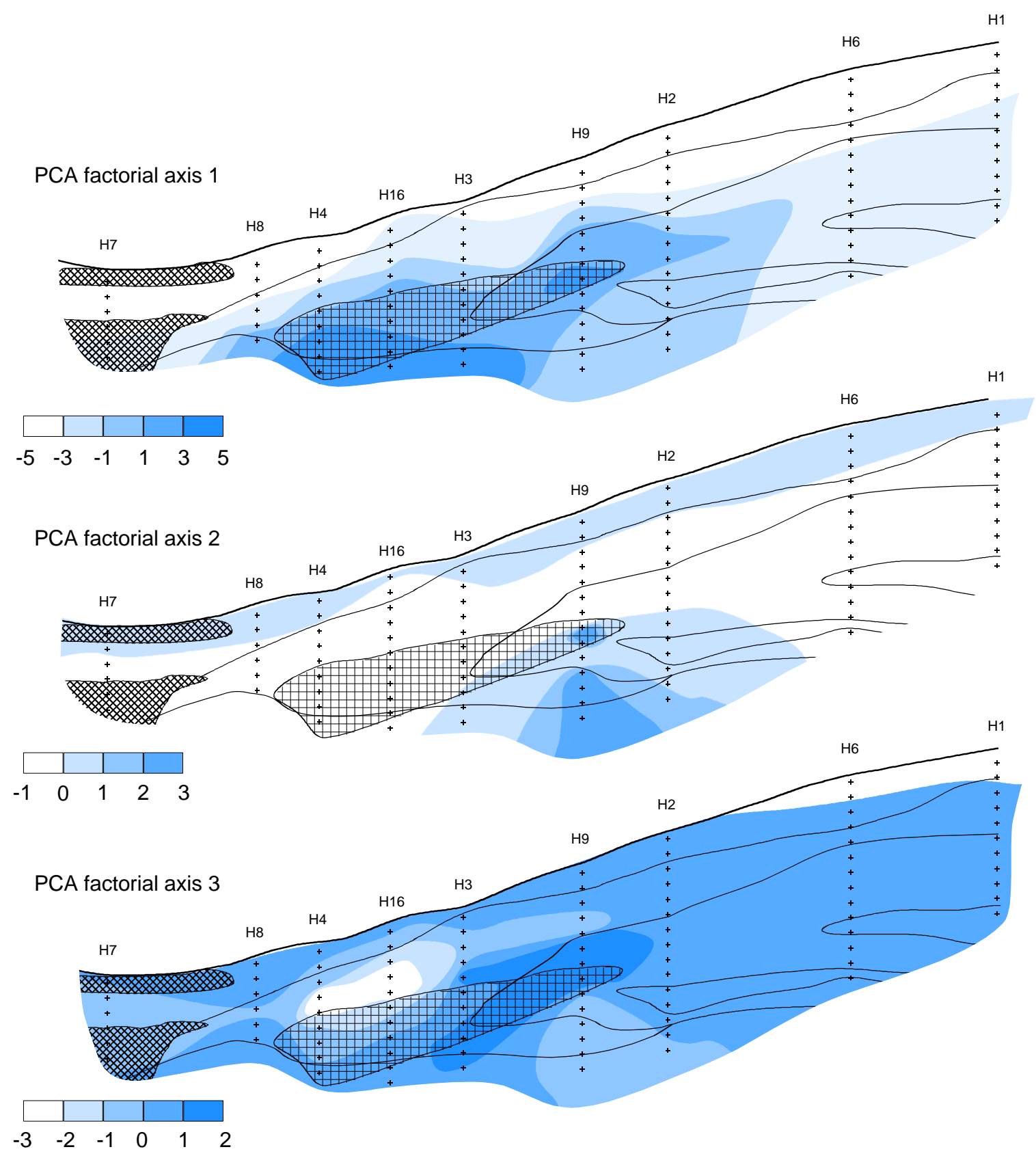

Fig. 8 : Distribution of the 3 main factorial axes along the transect T (PCA carried out on saturated extracts). Factorial axis 1, 2 and 3 explain $60.9 \%, 13.5 \%$ and $10.4 \%$ of the variance, respectively. 

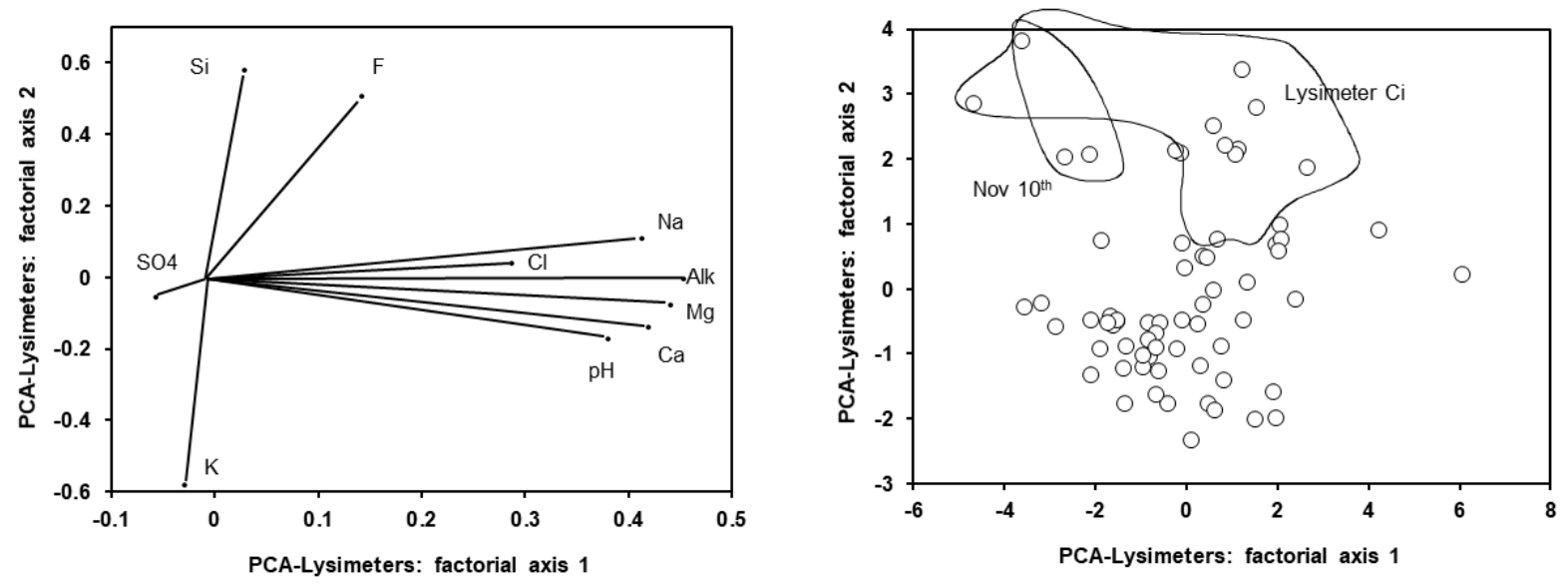

Fig. 9 : Variable and sample distributions on the first factorial plan of the PCA carried out on lysimeter samples. 


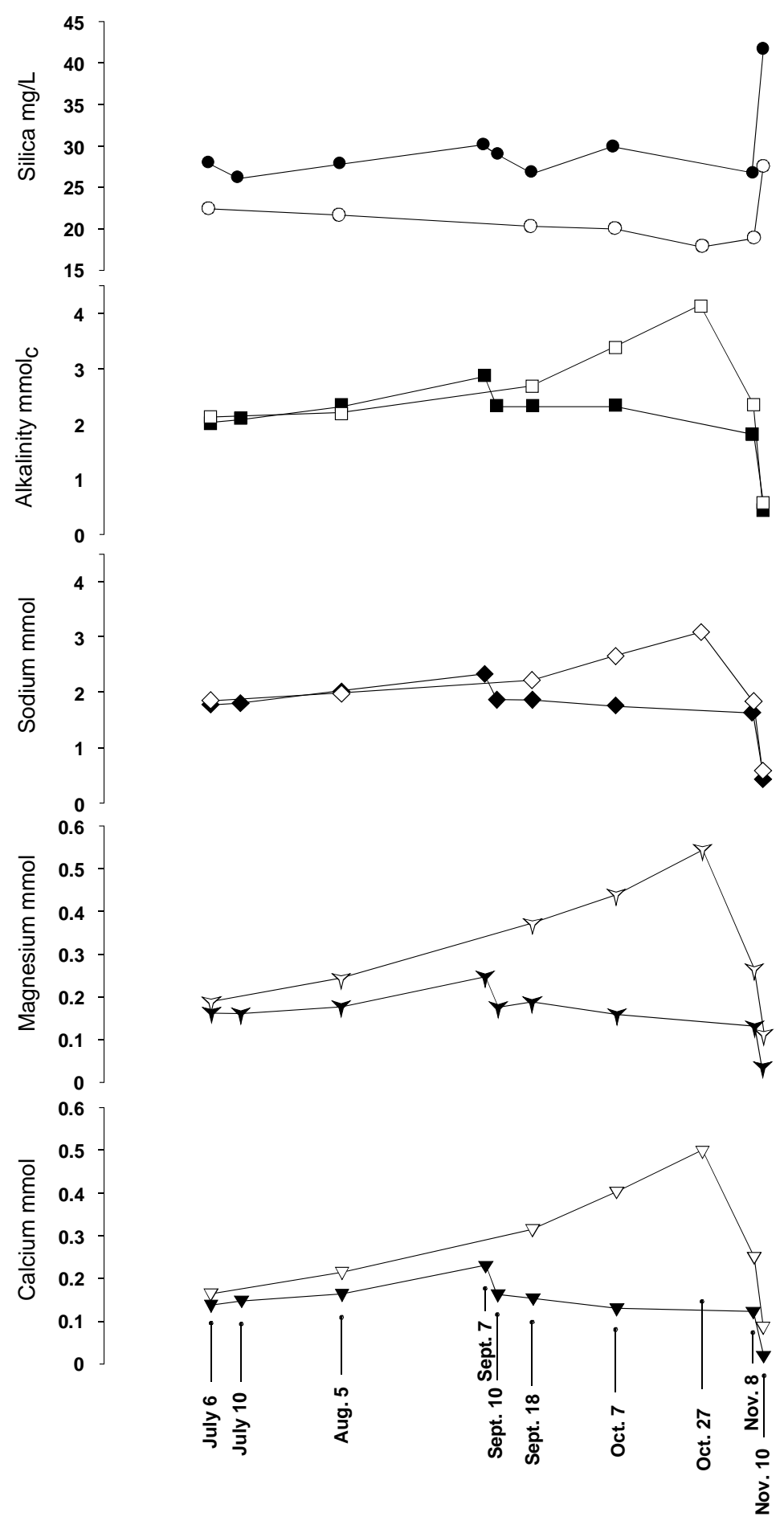

Wet season 2006

Fig. 10. Monitoring the chemistry profile in lysimeters $C_{i}$ (closed symbols) and $C_{h}$ (open symbols) during the wet season of 2006. Note the changes occurring between November $8^{\text {th }}$ and $10^{\text {th }}$. 

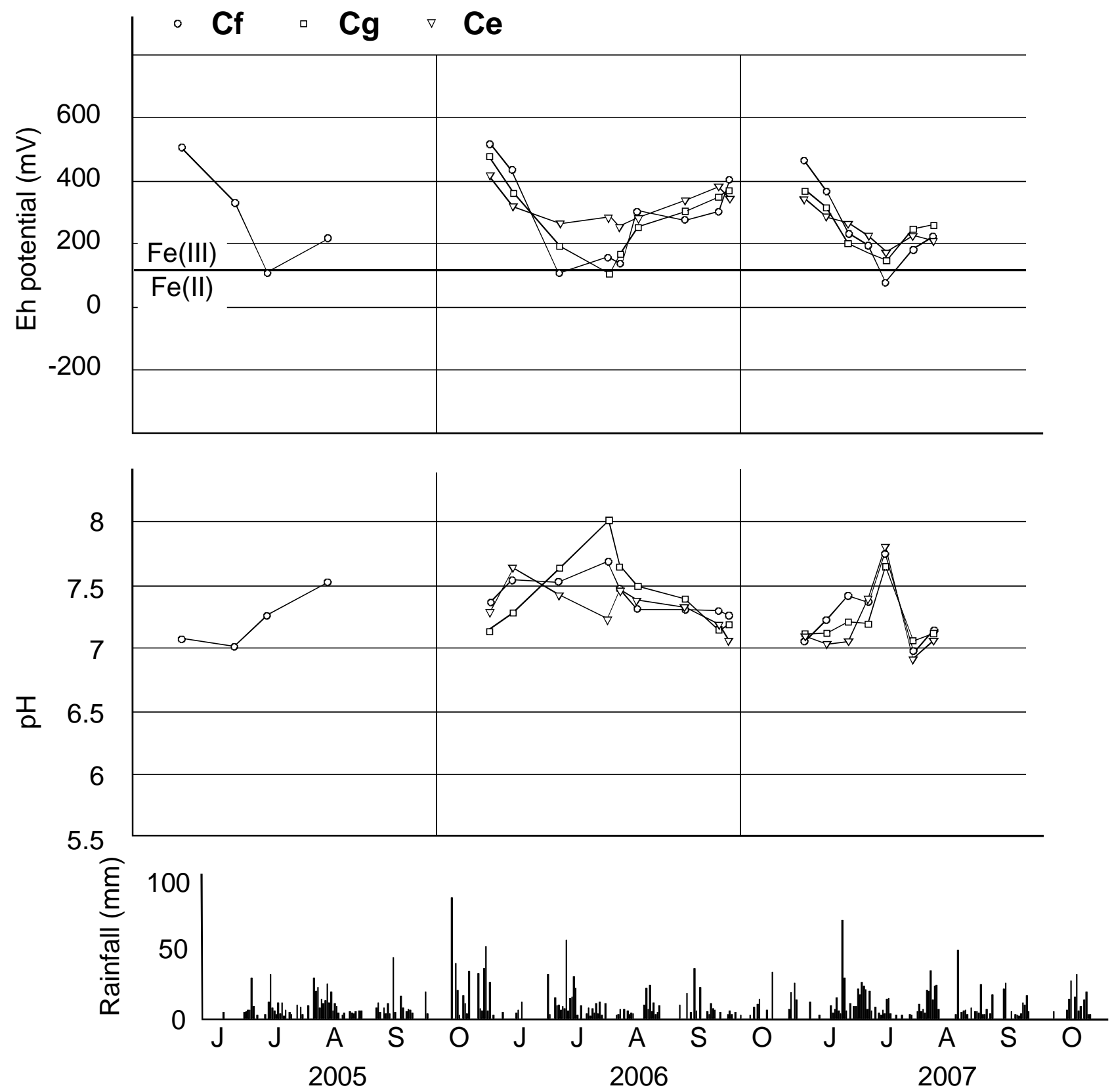

Fig. 11: Eh-pH monitoring along the depression (transect S) for 2005-, 2006- and 2007-wet seasons. 

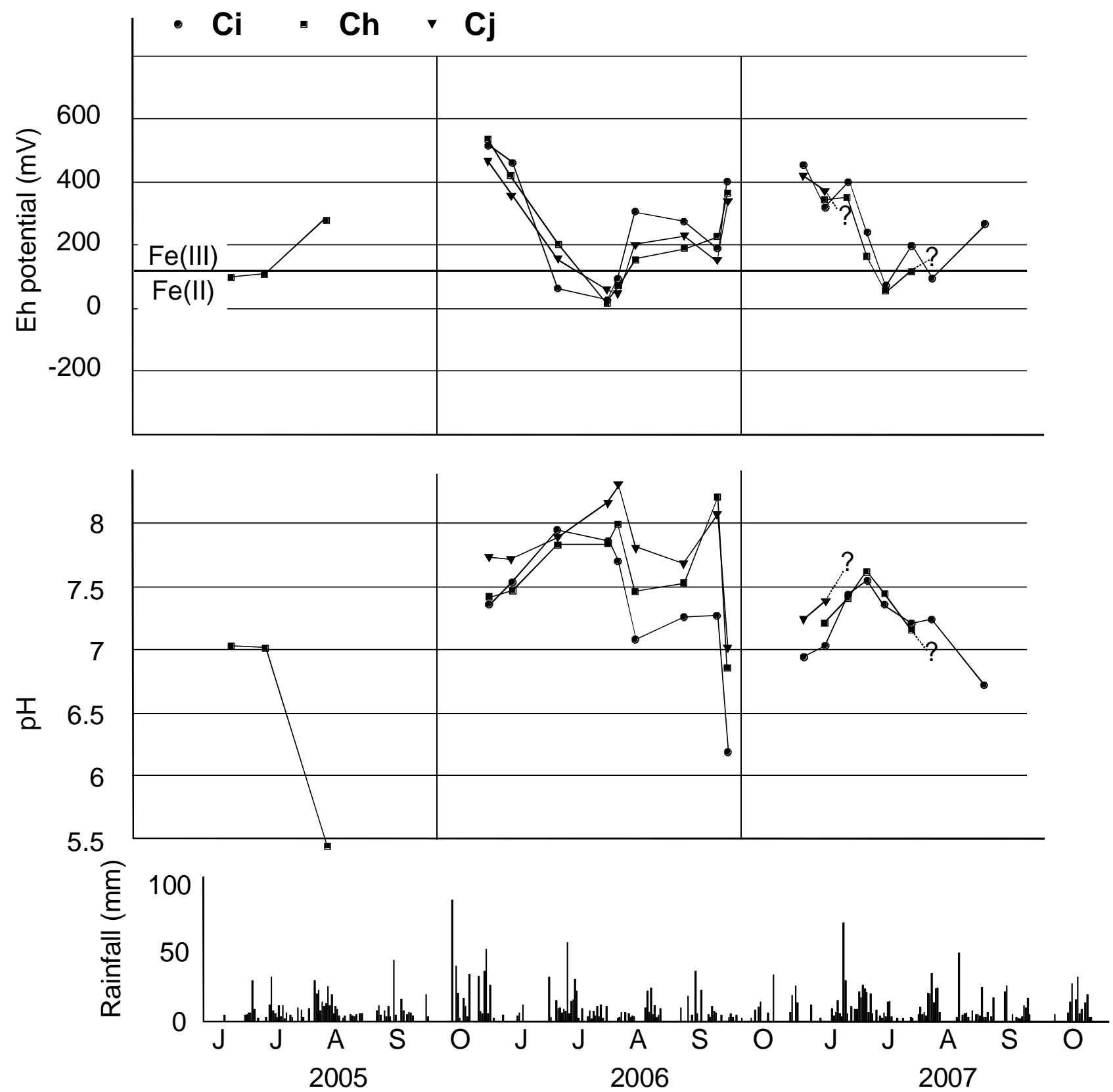

Fig. 12 : Eh-pH monitoring along the transect T for 2005-, 2006- and 2007-wet seasons. 